\title{
Small-scale patterns of nekton use among marsh and adjacent shallow nonvegetated areas of the Galveston Bay Estuary, Texas (USA)
}

\author{
Lawrence P. Rozas*, Roger J. Zimmerman
}

NOAA/National Marine Fisheries Service, Southeast Fisheries Science Center, 4700 Avenue U, Galveston, Texas 77551-5997, USA

\begin{abstract}
We quantified and compared nekton and infaunal densities among vegetated (edge Spartina alterniflora, inner Spartina alterniflora, Scirpus maritimus, Juncus roemerianus, and Spartina patens marsh) and shallow nonvegetated (marsh pond, marsh channel, cove, and shallow bay) areas of upper Galveston Bay and East Bay, Texas. In 2 seasons (spring and fall) of high nekton abundance, and over 2 yr, we collected 267 quantitative samples (upper Galveston Bay, 1993=127 and East Bay, 1994=140) using a $1 \mathrm{~m}^{2}$ drop sampler. The vegetated marsh surface consistently contained more species (i.e. higher species richness) and total numbers of decapod crustaceans than nonvegetated areas. In contrast, fish species richness and densities of total fishes on the marsh and in nonvegetated areas were not significantly different in most comparisons. Most numerically dominant species of nekton seemed to exhibit at least some degree of habitat selection. Within vegetation, 2 factors, elevation and proximity to open water, were most important in influencing the distribution of nekton. Low marsh edge dominated by Spartina alterniflora or Scirpus maritimus was apparently selected by most species that used the marsh surface including brown shrimp Farfantepenaeus aztecus, blue crab Callinectes sapidus, and daggerblade grass shrimp Palaemonetes pugio. White shrimp Litopenaeus setiferus and striped mullet Mugil cephalus also were concentrated in low edge marsh; although in one comparison, densities of these 2 species in edge and inner S. alterniflora were not significantly different. In contrast, gulf killifish Fundulus grandis and sheepshead minnow Cyprinodon variegatus were most abundant on inner S. alterniflora or S. patens marsh. Other fishes (gulf menhaden Brevoortia patronus, spot Leiostomus xanthurus, bay anchovy Anchoa mitchilli, blackcheek tonguefish Symphurus plagiusa, and Atlantic croaker Micropogonias undulatus) had higher densities over nonvegetated bottoms than on the marsh surface. Specific habitat types that these pelagic species seemed to favor were marsh channels (gulf menhaden, bay anchovy), marsh ponds (spot), and coves (Atlantic croaker, blackcheek tonguefish). Overall, marsh-surface and adjacent nonvegetated habitat types contained much higher densities of most nekton than the shallow bay. Infaunal densities were estimated from sediment cores, and taxa (mainly annelids, crustaceans, molluscs, and insects) were most abundant in nonvegetated areas contiguous with marsh in the spring. Factors that influenced infaunal abundance are complex and may include predation, flooding patterns, elevation, and distance to edge. Our study has important implications for designing marsh-creation projects. Based on our results, we recommend creating a variety of marsh and contiguous shallow-water areas to enhance nekton biodiversity. To maximize fishery habitat, priority should be given to constructing low marsh edge by creating large areas of low marsh interspersed with a dense network of shallow channels and interconnected ponds.
\end{abstract}

KEY WORDS: Fishery species - Gulf of Mexico - Habitat comparisons - Habitat selection - Nursery areas - Penaeid shrimps - Tidal marsh - Restoration

\section{INTRODUCTION}

Shallow areas along estuarine shorelines often contain large nekton populations, reflecting the high productivity of estuaries (Pihl \& Rosenberg 1982, Kneib 1997). Here, aquatic organisms use a complex habitat

•E-mail: lawrence.rozas@noaa.gov mosaic composed of tidal marshes and adjacent intertidal and subtidal waters (Kneib 1997). The different habitat types that compose this mosaic are not only connected by proximity, but also by tidal flow. Many natant organisms, for example, move freely between the vegetated marsh surface and contiguous open water as water level changes with tide stage (Zimmerman \& Minello 1984, McIvor \& Odum 1988, Hettler 
1989, Rozas \& Reed 1993, Kneib \& Wagner 1994, Kneib \& Knowlton 1995, Irlandi \& Crawford 1997, Cicchetti 1998).

Tidal marshes are widely recognized as important nursery areas that support valuable coastal fisheries (Boesch \& Turner 1984, Minello 1999, Zimmerman et al. 2000). The young of many fishery species and all life stages of numerous estuarine resident species use the flooded marsh surface much more intensively than adjacent nonvegetated bottom (Zimmerman \& Minello 1984, Thomas et al. 1990, Rakocinski et al. 1991, Baltz et al. 1993, Wenner \& Beatty 1993, Minello et al. 1994, Castellanos 1997, Rozas \& Minello 1998, Howe et al. 1999, Minello 1999). Tidal marsh channels connect the marsh surface with open estuarine waters. These channels appear to be used as nursery areas by some organisms, and subtidal channels serve as low-tide refugia and staging areas for animals using adjacent intertidal areas (Cain \& Dean 1976, Hackney et al. 1976, Rozas \& Hackney 1984, Rozas \& Odum 1987, Rozas et al. 1988, Rountree \& Able 1992, Cattrijsse et al. 1994). Whether marsh ponds function similarly to tidal channels may depend on their hydrology. Marsh ponds that are constantly flooded and hydrologically connected to tidal channels support relatively high nekton populations (Rogers et al. 1992). In contrast, isolated ponds apparently support fewer organisms because limited tidal exchange with adjacent waterways restricts recruitment, and animals confined within these ponds must withstand rigorous environmental conditions (Rowe \& Dunson 1995) and competition for food (Layman 1999).

The literature comparing the use of major habitat types in the shallow region of estuaries is limited. Most studies comparing nekton populations in estuarine marshes were conducted in salt marsh dominated by a single species, Spartina alterniflora Loisel. Little information exists about how nekton use marsh vegetation dominated by species other than $S$. alterniflora. In addition, comparisons of different habitat types employing quantitative methods are limited, and few studies have examined major habitat types concurrently. Assessment of the relative habitat value of tidal marsh and adjacent areas is best accomplished through comparisons of nekton densities using quantitative gear and by sampling all sites at the same time (Rozas \& Minello 1997).

The overall objective of our study was to examine nokton use of marsh and rontiguous open-water areas within a shallow region of Galveston Bay, Texas, USA, by coinparing the small-scale distribution of organisms among major habitat types. Our study was part of a larger project to build a database from which design parameters could be developed for constructing ecologically functional marshes using dredged material
(Rozas \& Zimmerman 1994, Rozas et al. 1995). Specific goals of our study were to: (1) compare densities of dominant species of fishes and decapod crustaceans (as a measure of habitat quality) among major marsh and shallow nonvegetated areas of Galveston Bay, (2) describe the composition, relative abundance, and seasonal abundance of fishes, decapod crustaceans, and infauna using these areas, and (3) identify the habitat attributes that could account for the distributional patterns we observed.

\section{MATERIALS AND METHODS}

Study area. Our study area included 2 locations on the north Texas coast in the Galveston Bay estuary, upper Galveston Bay and East Bay (Fig. 1). The Galveston Bay system is microtidal. Tides within the study area are predominantly diurnal, and the mean tidal range is approximately $0.3 \mathrm{~m}$ (Orlando et al. 1991).

The upper Galveston Bay location encompassed the marsh complex and adjacent open water of Atkinson Island and Hog Island. Salt marsh occupies the intertidal zone, and the dominant plant species within the marsh vary with elevation (Wermund et al. 1992). Spartina alterniflora is present in the low intertidal zone, and the most robust form of this species occurs in narrow bands at the marsh edge adjacent to subtidal and low, nonvegetated intertidal areas. Scirpus maritimus L. is found at slightly higher elevations, but it too occurs low enough in the intertidal zone to experience frequent flooding events. Spartina patens (Aiton) Muhl grows in the highest part of the intertidal zone and floods only infrequently. Nonvegetated shallowwater areas within and contiguous with the marsh vegetation in the study area include channels, ponds, and coves. Coves are large semi-enclosed embayments that are subjected to less wave energy than bay waters because they are partially surrounded by marsh.

The East Bay location was centered on a large salt marsh system at Elmgrove Point on the bay side of the Bolivar Peninsula (Fig. 1). As in upper Galveston Bay, Spartina alterniflora is the dominant vegetation of the low intertidal marsh at East Bay. However, S. patens and Scirpus maritimus are not major marsh types at the East Bay location; rather, Juncus roemerianus Scheele replaces $S$. alterniflora at the higher intertidal elevations; Juncus marsh is most extensive at the northeast portion of the Elmgrove Point marsh.

Nekton/infauna sampling. Nekton (fishes and decapod crustaceans) were quantitatively sampled with a drop sampler using the procedure described by Zimmerman et al. (1984). We chose a drop sampler for this study because the catch efficiency of this enclosure device does not appear to vary substantially with habi- 
tat characteristics typical of shallow estuarine areas, and unlike many other gear, it is effective in dense emergent vegetation (Rozas \& Minello 1997). We employed a $1.14 \mathrm{~m}$ diameter cylinder that was dropped from a boom attached to a shallow-draft boat. Two persons positioned the cylinder over a sample site by slowly pushing from the boat's stern. When released from the boom, the cylinder rapidly entrapped organisms within a $1.0 \mathrm{~m}^{2}$ sample area. Disturbance to the sample area prior to releasing the cylinder was minimized using this procedure, as distances from the bow and stern of the boat to the edge of the sample area were 3.5 and $8.3 \mathrm{~m}$, respectively.

We sampled 8 distinct areas within the marsh complex and adjacent shallow water in upper Galveston Bay that included 4 vegetated areas ledge Spartina alterniflora, inner $S$. alterniflora, S. patens, and Scirpus marsh) and 4 shallow nonvegetated areas (marsh pond, marsh channel, marsh cove, and shallow bay

waters). Ponds were not isolated hydrologically but connected to tidal marsh creeks. Sample sites in inner S. alterniflora marsh were 5 to $6 \mathrm{~m}$ from the marsh edge (vegetation-water interface), whereas samples of other vegetated areas were taken within 1 to $2 \mathrm{~m}$ of the marsh edge. Although all vegetated areas except inner $S$. alterniflora marsh can be classified as marsh edge, for brevity, 'edge' will be used as a modifier only with $S$. alterniflora to distinguish this habitat type from inner $S$. alterniflora marsh. We collected a total of 127 nekton samples during 2 seasons in 1993: spring (May 5-7, 21) and fall (October 12, 18-20). Most habitat types were sampled 8 times each season. However, we collected only 7 shallow bay samples in the fall. We based the number of samples collected at each island (Atkinson Island or Hog Island) in a particular habitat type on the ratio of the area of a habitat type at an island to the total area of the habitat type (both islands combined).

In 1994, we sampled 7 areas in East Bay that included all habitat types sampled in upper Galveston Bay (except Spartina patens and Scirpus) as well as Juncus marsh. We took 10 replicate samples in each habitat type in spring (April 25-28) and fall (September 12-15), for a total of 140 nekton samples.
At each location, we randomly selected replicate sample sites using random numbers and a grid placed over an aerial photograph of the potential sample area. Shallow bay sample sites were selected from areas of Galveston Bay along the shoreline of each marsh system (Atkinson Island, Hog Island, East Bay marsh). We collected all samples during the day at high tide when all habitat types were inundated and available to aquatic organisms; sample sites were all $<1 \mathrm{~m}$ deep.

After the cylinder was dropped, we measured water temperature, dissolved oxygen, salinity, turbidity, and water depth using the methods described by Minello \& Zimmerman (1992). We also measured the distance from the sample area to the nearest marsh-water interface. At vegetated sites, we clipped plant stems at ground level, counted them (dead and alive combined), and removed them from the cylinder. We also determined the standing biomass of vegetation each season by oven drying 3 air-dried subsamples of each species at $75^{\circ} \mathrm{C}$ to a constant weight and calculating a conversion factor (oven-dried weight/air-dried weight) using these data. By multiplying the total air-dried weight of each species in each sample by the appropri- 
ate conversion factor and totaling the weights within each sample, we converted all values to oven-dried biomass.

In each major habitat type each season, we collected 5 (upper Galveston Bay) or 6 (East Bay) samples for benthic infauna. Each replicate sample consisted of 3 pooled $5 \mathrm{~cm}$-deep cores taken from randomly selected locations within the cylinder with a $5 \mathrm{~cm}$ diameter plastic core (total area $=60.8 \mathrm{~cm}^{2}$ ). Samples were washed on a $0.5 \mathrm{~mm}$ mesh sieve, and the material retained was fixed with $10 \%$ formalin stained with Rose Bengal. In the laboratory, organisms were separated from detritus and plant parts and identified to the lowest feasible taxon.

After we measured environmental parameters and collected benthic cores, we captured nekton trapped in the drop sampler using dip nets and by filtering the water pumped out of the enclosure through a $1 \mathrm{~mm}$ mesh net. When the sampler was completely drained, any animals remaining on the bottom were removed by hand. Samples were preserved in formalin with Rose Bengal stain and returned to the laboratory for processing. In the laboratory, the samples were sorted, and animals were identified to lowest feasible taxon.

Flooding duration. The Conrad Blucher Institute for Surveying and Science, Texas A\&M University-Corpus Christi supplied us with water-level data. We used continuously collected water-level data for 1993 and 1994 from Morgans Point (NOS Station I.D. = 87700613 ) and Pier 21 (NOS Station I.D. $=8771450$ ) to estimate flooding durations at each location. Using water depth measured at each sample site in upper Galveston Bay and concurrent water-level data from Morgans Point (located approximately $1 \mathrm{~km}$ west of Atkinson Island, Fig. 1), we estimated substrate elevation relative to this tide gauge and determined flooding duration (percentage of time a site was submerged) for each sample site.

We used an equation from Minello \& Webb (1997) to compute water levels in East Bay from Pier 21 (located approximately $20 \mathrm{~km}$ south-southwest of Elmgrove Point, Fig. 1) data because our East Bay location lacked a nearby tide gauge. This equation incorporates a $2 \mathrm{~h}$ lag in tides between Elmgrove Point and Pier 21 (i.e. tides reached the East Bay location 2 h after Pier 21), and there is good agreement between tide levels at Pier 21 and water levels in East Bay (Minello \& Webb 1997). We estimated elevations and flooding durations of East Bay sample sites by relating the water depth measured at each site to concurrent East Bay tide data computed from this equation

We also estimated a mean surface elevation (relative to Mean Tide Level, MTL) for each habitat type at a location. This elevation was estimated at each location by subtracting the MTL of the nearest tide gauge from the average substrate elevation that was determined as described above. The MTL used for habitat types at the East Bay location was calculated from the MTL of the Pier 21 gauge using the equation from Minello \& Webb (1997).

Data analyses. We used 1-way analysis of variance (ANOVA) followed by a priori contrasts to examine differences in densities of abundant organisms, species richness (number of fish and decapod crustacean taxa), and environmental characteristics (mean dissolved oxygen, salinity, water temperature, turbidity, water depth, distance to edge, and vegetation stem density and biomass) among habitat types (Table 1). In this procedure, we analyzed the data collected at each location (upper Galveston Bay and East Bay) and during each season separately, because many species were only abundant enough to include in the statistical analysis at 1 location or in 1 season. We considered alpha levels of 0.05 to be significant in all results, but we also calculated adjusted alpha levels for the Habitat effect using the sequential Bonferroni method described by Rice (1989). These adjusted levels should be used if the reader would like to buffer against error introduced by making multiple comparisons (i.e. testing a hypothesis for several species or parameters). We compared the following habitat types with a prioricontrasts (Table 1). Upper Galveston Bay: all vegetated areas versus all nonvegetated areas, edge Spartina alterniflora versus Scirpus, edge $S$. alterniflora versus $S$. patens, edge $S$. alterniflora versus inner $S$. alterniflora, inner $S$. alterniflora versus Scirpus, inner $S$. alterniflora versus $S$. patens, and $S$. patens versus Scirpus; East Bay: all vegetated areas versus all nonvegetated areas, edge $S$. alterniflora versus Juncus, edge $S$. alterniflora versus inner $S$. alterniflora, and inner $S$ alterniflora versus Juncus.

We used 8 predictor variables (salinity, water temperature, dissolved oxygen, turbidity, distance to edge, water depth, stem density, and elevation) in 2 discriminant function analyses to distinguish among habitat types. From the first analysis, we constructed a discriminant model that used these environmental variables to separate the 9 habitat types we sampled. We used the Wilks' lambda multivariate test statistic to determine whether habitat types could be separated, and we examined the canonical variates in the model to identify the most important predictor variables in determining this separation. In a second discriminant analysis, we used this same procedure to distinguish among the 5 marsh types we sampled. We used 2 canonical analyses to examine potential relationships between densities of fishes and decapod crustaceans and environmental characteristics of habitats. In the first canonical analysis, we included data from all habitats. We used onily data collected at marsh sites in the 
Table 1. Analysis of Variance (ANOVA) table for comparing habitat types. Model includes the test for the main effect of Habitat and the a priori contrasts that compare specific habitat types. The example presented here uses data from upper Galveston Bay and the dependent variable total macrofauna (sum of total fishes and total crustaceans)

\begin{tabular}{|c|c|c|c|c|c|}
\hline Source & df & $\begin{array}{l}\text { Sum of } \\
\text { squares }\end{array}$ & $\begin{array}{l}\text { Mean } \\
\text { square }\end{array}$ & $F$ value & p value \\
\hline \multicolumn{6}{|l|}{ May 1993} \\
\hline Habitat & 7 & 27.896 & 3.985 & 4.293 & 0.0007 \\
\hline \multicolumn{6}{|l|}{ Contrasts } \\
\hline Vegetated vs nonvegetated habitat types & 1 & 14.184 & 14.184 & 15.281 & 0.0003 \\
\hline Edge Spartina alterniflora vs Scirpus manitimus & 1 & 4.062 & 4.062 & 4.376 & 0.0410 \\
\hline Edge Spartina alterniflora vs Spartina patens & 1 & 6.152 & 6.152 & 6.628 & 0.0127 \\
\hline Edge Spartina alterniflora vs inner Spartina alterniflora & 1 & 3.853 & 3.853 & 4.151 & 0.0463 \\
\hline Inner Spartina alterniflora vs Scirpus maritimus & 1 & 0.003 & 0.003 & 0.003 & 0.9567 \\
\hline Inner Spartina alterniflora vs Spartina patens & 1 & 0.268 & 0.268 & 0.288 & 0.5934 \\
\hline Spartina patens vs Scirpus maritimus & 1 & 0.216 & 0.216 & 0.233 & 0.6313 \\
\hline Residual error & 56 & 51.982 & 0.928 & & \\
\hline \multicolumn{6}{|l|}{ October 1993} \\
\hline Habitat & 7 & 35.362 & 5.052 & 5.721 & 0.0001 \\
\hline \multicolumn{6}{|l|}{ Contrasts } \\
\hline Vegetated vs nonvegetated habitat types & 1 & 19.391 & 19.391 & 21.961 & 0.0001 \\
\hline Edge Spartina alterniflora vs Scirpus maritimus & 1 & 0.696 & 0.696 & 0.788 & 0.3786 \\
\hline Edge Spartina alterniflora vs Spartina patens & 1 & 11.361 & 11.361 & 12.866 & 0.0007 \\
\hline Edge Spartina alterniflora vs inner Spartina alterniflora & 1 & 5.828 & 5.828 & 6.600 & 0.0129 \\
\hline Inner Spartina alterniflora vs Scirpus maritimus & 1 & 2.496 & 2.496 & 2.827 & 0.0984 \\
\hline Inner Spartina alterniflora vs Spartina patens & 1 & 0.915 & 0.915 & 1.036 & 0.3132 \\
\hline Spartina patens vs Scirpus maritimus & 1 & 6.434 & 6.434 & 7.286 & 0.0092 \\
\hline Residual error & 55 & 48.564 & 0.883 & & \\
\hline
\end{tabular}

second canonical analysis. We combined the data collected at each location and during each season in both multivariate procedures (discriminant function and canonical analyses) described above.

Densities of animals were positively related to the standard deviation; therefore, we performed a $\ln (x+1)$ transformation of the original density values prior to analyses. Other variables were not transformed. All tabular and graphical data presented in this paper are untransformed means. We used SuperANOVA (Version 5 edn, Abacus Concepts, Inc., Berkeley, California, 1989) to do 1-way ANOVA and SAS (Version 6, SAS Institute, Cary, NC, 1989) to run the canonical and discriminant function analyses.

\section{RESULTS}

\section{Decapod crustaceans and fishes}

At upper Galveston Bay, we collected a total of 21 species of fishes and 10 species of crustaceans in spring; and 17 species of fishes and 8 species of crustaceans in fall (Table 2). We recorded slightly more species from East Bay: 22 species of fishes and 15 species of crustaceans in spring; 25 species of fishes and 16 species of crustaceans in fall (Table 3). Marsh sites consistently yielded significantly more species (i.e. higher species richness; ANOVA Contrasts, all p values = 0.0001 ) and total numbers of crustaceans than nonvegetated areas (both locations and seasons, Tables 2 \& 3). In contrast, fish species richness and densities of total fishes in marsh and nonvegetated areas were not significantly different in most comparisons (ANOVA Contrasts, Upper Galveston Bay, $\mathrm{p}=0.0869$ [spring], $p=0.7591$ [fall]; East Bay, $p=0.9243$ [fall]); although at East Bay in spring, we took significantly more fish species (ANOVA Contrast, $p=0.0001$, means $=2.5$ vs 1.2 ), and total fishes (means $=43.9$ vs 6.1 , see Table 5 ) in nonvegetated areas than at marsh sites.

\section{Upper Galveston Bay}

Decapod crustaceans (49\%) and fishes (51\%) were similarly abundant in spring, but decapods accounted for $90 \%$ of all animals taken in fall at upper Galveston Bay sample sites (Table 2). Daggerblade grass shrimp Palaemonetes pugio, brown shrimp Farfantepenaeus aztecus (formerly Penaeus aztecus, Perez-Farfante \& Kensely 1997), white shrimp Litopenaeus setiferus (formerly Penaeus setiferus, Perez-Farfante \& Kensely 1997), blue crab Callinectes sapidus, gulf marsh fiddler crab Uca longisignalis, heavy marsh crab Sesarma reticulatum, and marsh grass shrimp Palaemonetes vulgaris accounted for $>95 \%$ of total decapod crustaceans 


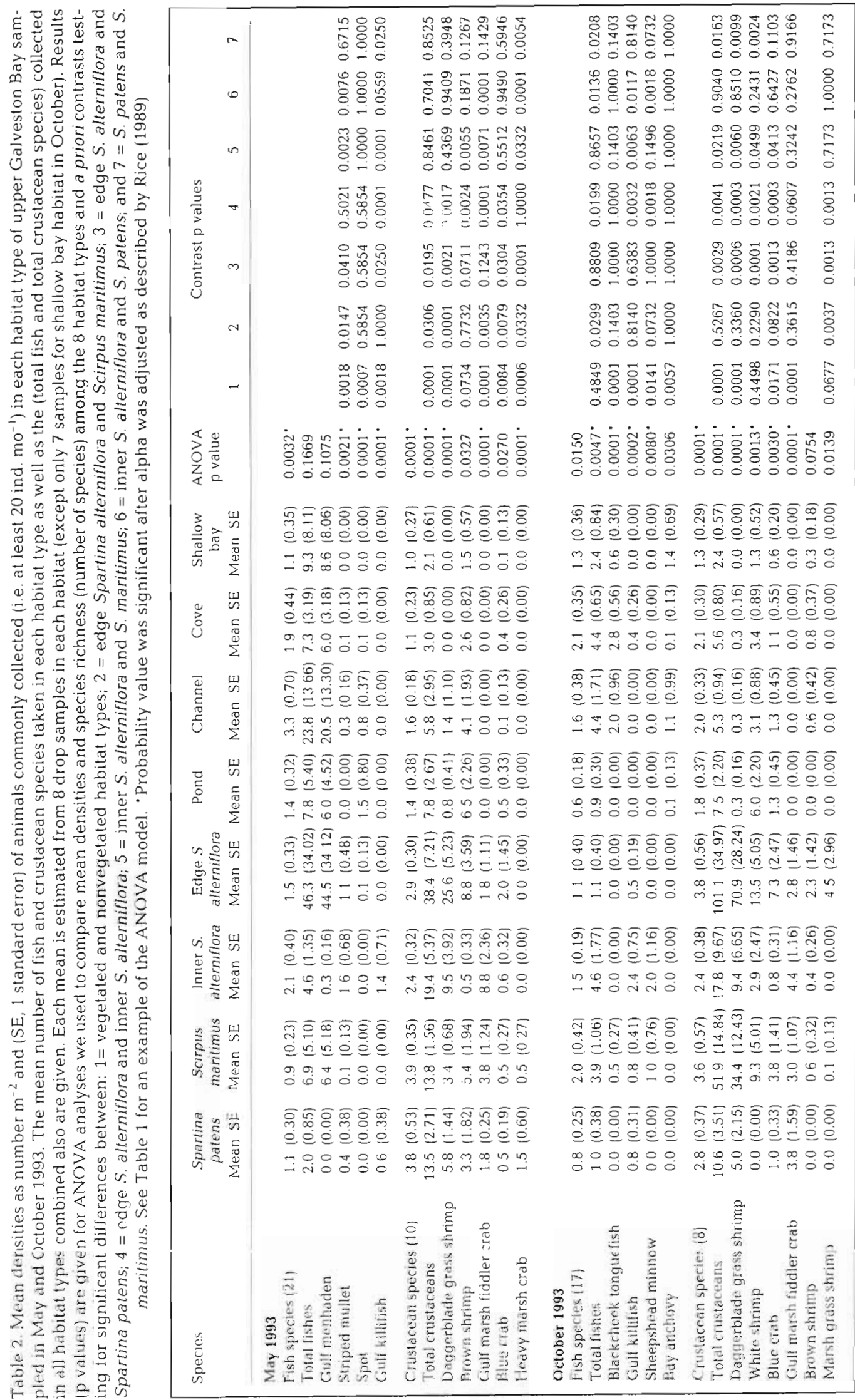




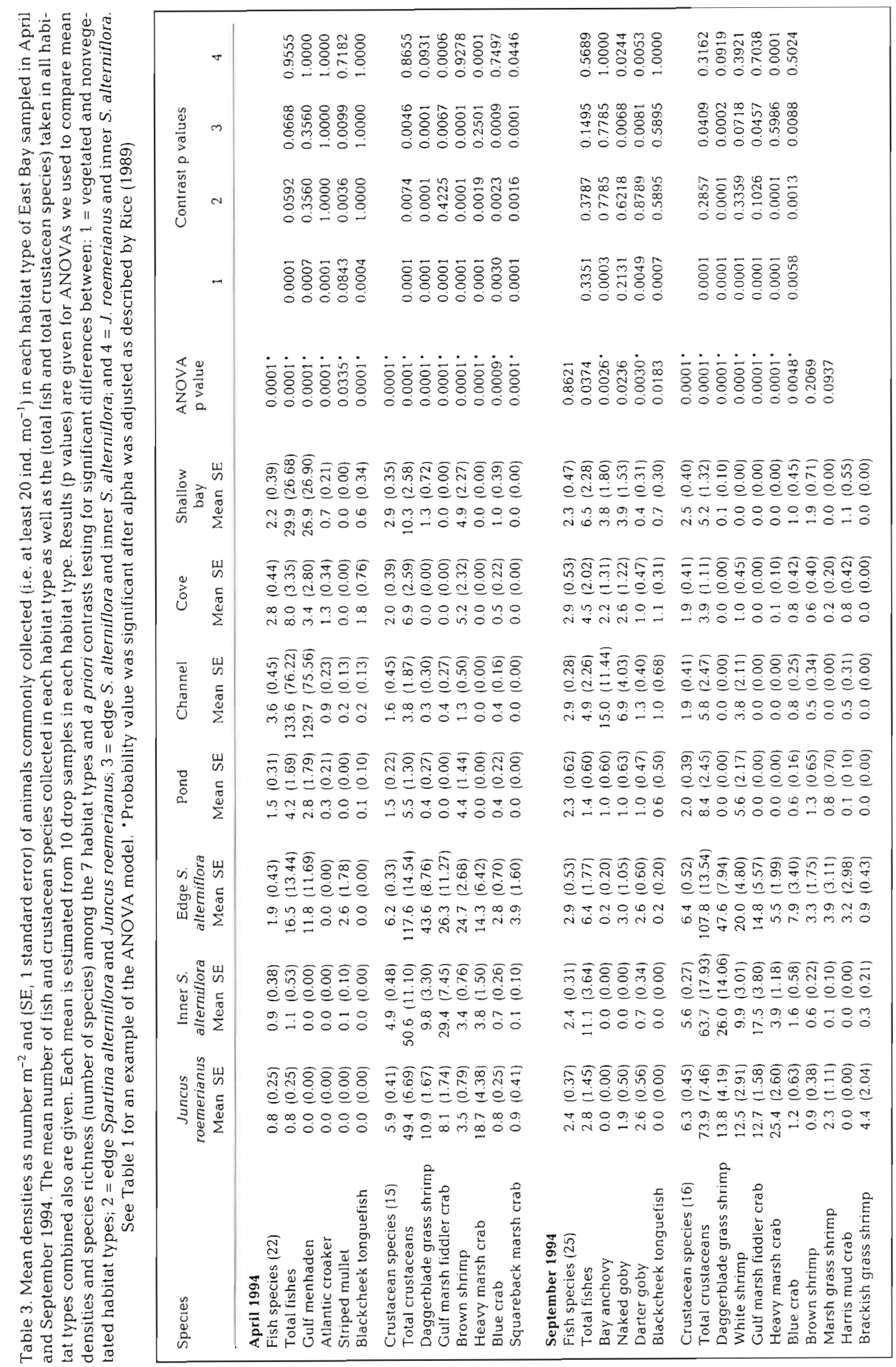




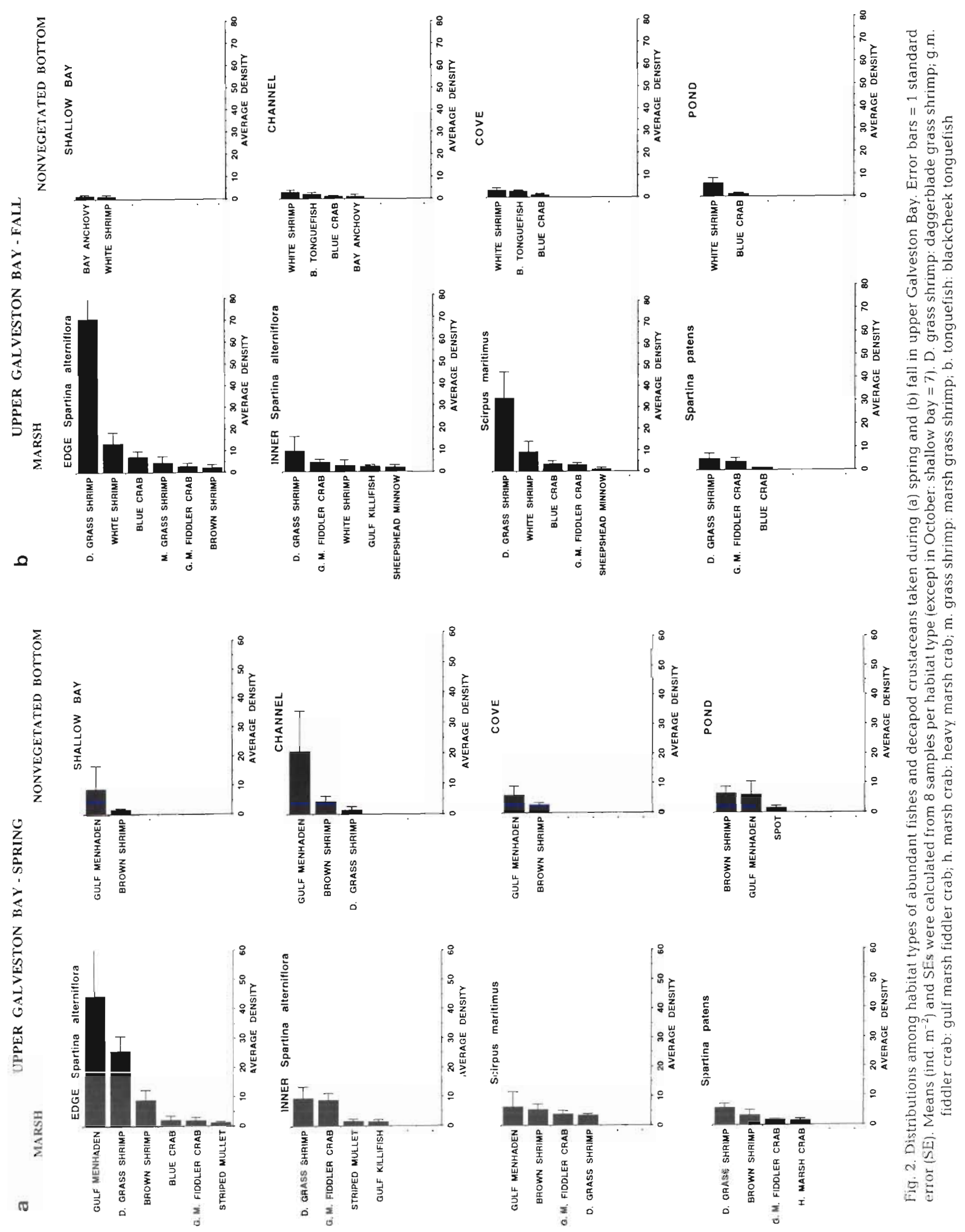


taken in our drop samples. Nine species numerically dominated the fish assemblage in upper Galveston Bay, and accounted for $>95$ and $>75 \%$ of fishes collected in spring and fall, respectively. Gulf menhaden Brevoortia patronus, striped mullet Mugil cephalus, spot Leiostomus xanthurus, and gulf killifish Fundulus grandis dominated the fish assemblage in spring (Table 2). In fall, gulf killifish, bay anchovy Anchoa mitchilli, blackcheek tonguefish Symphurus plagiusa, and sheepshead minnow Cyprinodon variegatus were most abundant (Table 2).

Species assemblages differed among habitat types (Table 2, Fig, 2). The assemblage of edge Spartina alterniflora marsh was numerically dominated by gulf menhaden, daggerblade grass shrimp, and brown shrimp in spring, and daggerblade grass shrimp, white shrimp, and blue crab in fall. Of the 3 other marsh types we sampled in upper Galveston Bay, Scirpus marsh had an assemblage most like that of edge $S$. alterniflora marsh. Gulf menhaden and brown shrimp in spring and daggerblade grass shrimp and white shrimp in fall dominated Scirpus marsh. Inner $S$. alterniflora marsh was dominated by gulf marsh fiddler crab and daggerblade grass shrimp. The assemblage of $S$. patens marsh was dominated by daggerblade grass shrimp, brown shrimp (spring), and gulf marsh fiddler crab (fall). Nonvegetated areas were dominated by gulf menhaden and brown shrimp in spring and white shrimp in fall.

The vegetated marsh surface contained high densities of decapod crustaceans and some fishes (Table 2, Fig. 2). Most decapod crustaceans were taken either exclusively at marsh sites (gulf marsh fiddler crab, heavy marsh crab, marsh grass shrimp) or were significantly more abundant in marsh than at nonvegetated sample sites (daggerblade grass shrimp, blue crab), although there were exceptions. In spring, mean densities of brown shrimp were relatively high in marsh channels and ponds, and similar to densities at marsh sites; therefore, brown shrimp densities did not differ significantly between marsh and nonvegetated sites (Table 2). In fall, white shrimp densities in marsh and nonvegetated areas were not significantly different due largely to an abundance of white shrimp in marsh ponds and their absence in Spartina patens marsh (Table 2). Three fishes also were strongly associated with the vegetated marsh surface. Striped mullet, gulf killifish, and sheepshead minnow all had higher densities in marsh than in nonvegetated areas (Table 2).

Apparent habitat selection also occurred among marsh types. We collected marsh grass shrimp (in fall) almost exclusively in edge Spartina alterniflora marsh, whereas 3 other species with an affinity for the marsh surface (gulf killifish, sheepshead minnow, and heavy marsh crab) were rarely or never collected in edge $S$. alterniflora marsh (Table 2). Scirpus marsh was similar to edge $S$. alterniflora marsh in that mean densities of brown shrimp (spring), blue crab (fall), and white shrimp (fall) in the 2 marsh types were not significantly different, and the densities of these species in Scirpus marsh were greater than in inner $S$. alterniflora marsh. Densities of gulf marsh fiddler crab and heavy marsh crab were greater in Scirpus marsh than in edge $S$. alterniflora marsh, whereas striped mullet, daggerblade grass shrimp, and blue crab in spring and marsh grass shrimp in fall were significantly less abundant in this habitat type than in edge $S$. alterniflora marsh (Table 2).

Although floristically similar, edge and inner Spartina alterniflora marshes differed substantially in animal densities (Table 2). Inner $S$. alterniflora marsh contained significantly fewer daggerblade grass shrimp, blue crab, brown shrimp in spring, and white shrimp and marsh grass shrimp in fall than edge $S$. alterniflora marsh. Compared with edge $S$. alterniflora marsh, inner $S$. alterniflora marsh had significantly higher densities of gulf killifish, gulf marsh fiddler crab (spring), and sheepshead minnow (fall). Densities of gulf killifish were higher in inner $S$. alterniflora marsh than in all other marsh types except $S$. patens in spring and higher than all other marsh types in fall (Table 2).

Of the other marsh types, Spartina patens marsh differed most in species and animal densities from edge $S$. alterniflora marsh (Table 2). Densities of daggerblade grass shrimp, blue crab, and striped mullet (spring) were relatively low in $S$. patens marsh when compared with their densities in edge $S$. alterniflora marsh. Other species were absent (e.g. white shrimp), or infrequently collected, from this marsh type. In contrast, densities of heavy marsh crab (spring) were higher in $S$. patens marsh than any other marsh type.

Several fishes exhibited an apparent affinity for open water. Spot, bay anchovy, and blackcheek tonguefish were all more abundant in nonvegetated areas than on the vegetated marsh surface (Table 2, Fig. 2). We collected bay anchovy exclusively in nonvegetated habitat types, and bay anchovy densities in fall were highest in the shallow bay. Blackcheek tonguefish was abundant in marsh channels and coves in fall. We collected most spot from marsh ponds and channels; none were taken in shallow bay waters (Table 2).

We also collected 10 species of molluscs, although our sampling technique was not designed to quantitatively sample benthic infauna. Most molluscs were taken from emergent marsh habitats and consisted mainly of marsh periwinkle Littoraria irrorata and eastern melampus Melampus bidentatus. Marsh periwinkle was most abundant in Scirpus maritimus and inner Spartina alterniflora marsh. Eastern melampus densities were highest in $S$. patens and inner $S$. alterniflora marsh. 


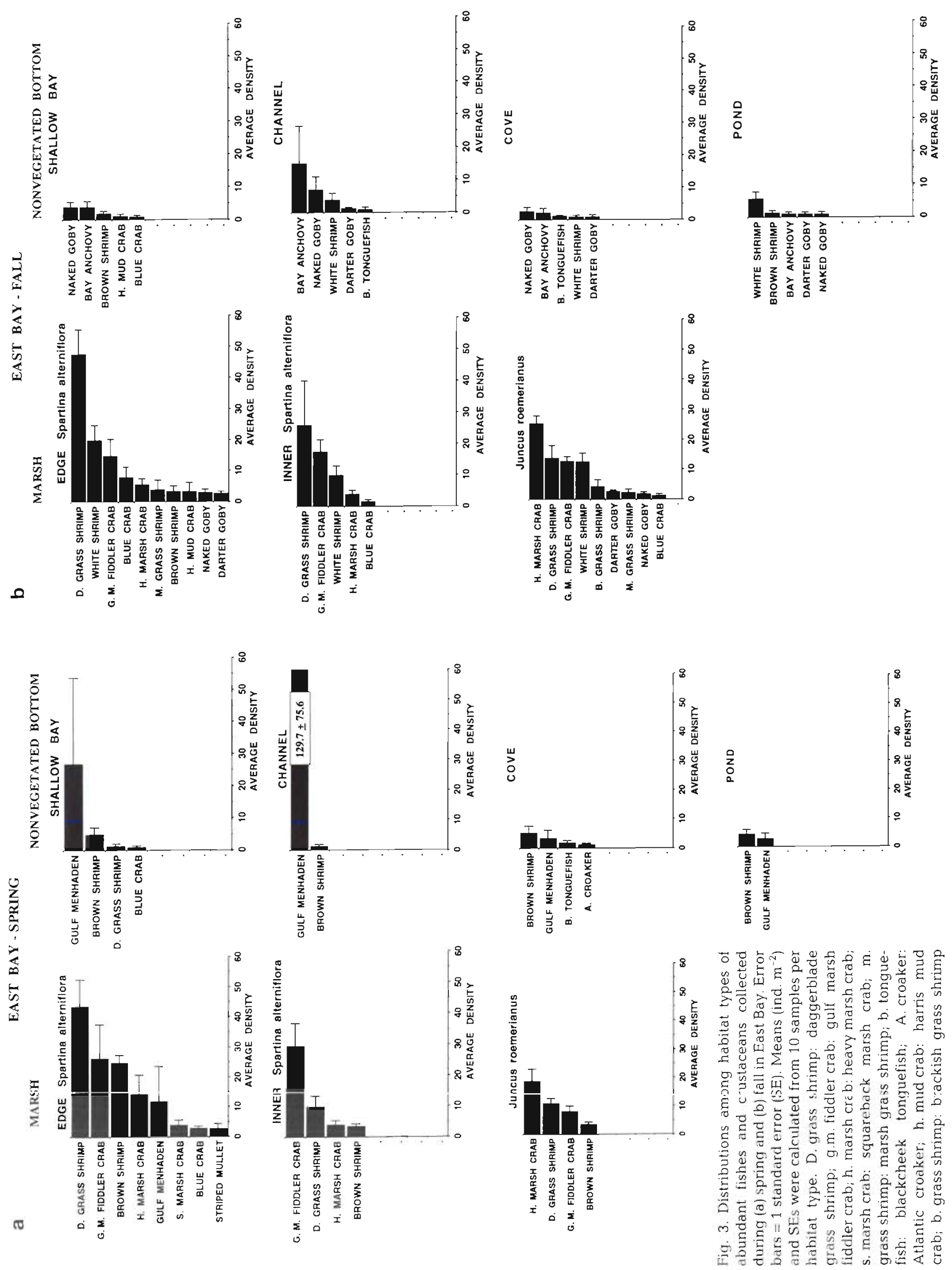




\section{East Bay}

Crustaceans were more numerous than fishes at East Bay both in spring ( 56 vs $44 \%$ ) and in fall ( 81 vs $19 \%$ ). Ten species dominated the decapod crustacean assemblage at East Bay. Daggerblade grass shrimp, gulf marsh fiddler crab, heavy marsh crab, brown shrimp, white shrimp, blue crab, squareback marsh crab Sesarma cinereum, Harris mud crab Rhithropanopeus harrisii, marsh grass shrimp, and brackish grass shrimp Palaemonetes intermedius accounted for $>95$ and $>97 \%$ of total decapods taken in East Bay samples during spring and fall, respectively. Densities of most decapod crustaceans collected at East Bay were significantly greater in marsh than in nonvegetated areas (Table 3).

Seven species numerically dominated the fish assemblage at East Bay, and accounted for $>96$ and $>90 \%$ of fishes collected in spring and fall, respectively. Gulf menhaden, Atlantic croaker Micropogonias undulatus, striped mullet, and blackcheek tonguefish dominated the fish assemblage in spring, whereas bay anchovy, naked goby Gobiosoma bosc, darter goby Gobionellus boleosoma, and blackcheek tonguefish were most abundant in fall (Table 3). Although striped mullet, darter goby, and naked goby were associated with emergent vegetation, other numerically dominant fishes showed an apparent preference for nonvegetated sites. Gulf menhaden, Atlantic croaker, blackcheek tonguefish, and bay anchovy were all more abundant in nonvegetated areas than in marsh vegetation (Table 3 ).

The assemblage of edge Spartina alterniflora marsh species was dominated by daggerblade grass shrimp and gulf marsh fiddler crab in addition to brown shrimp in the spring and white shrimp in the fall (Fig. 3). Several other species (squareback marsh crab, striped mullet, gulf menhaden, Harris mud crab) were commonly taken from edge $S$. alterniflora marsh, but were rare or absent in collections from inner $S$. alterniflora or Juncus marshes.

Inner Spartina alterniflora marsh was numerically dominated by daggerblade grass shrimp, gulf marsh fiddler crab, and white shrimp (fall) (Fig. 3). Densities of gulf marsh fiddler crab were higher in inner $S$. alterniflora marsh than either edge $S$. alterniflora or Juncus marsh (Table 3). In contrast, significantly fewer daggerblade grass shrimp, brown shrimp, blue crab, naked goby, and darter goby were taken in inner than edge $S$. alterniflora marsh (Table 3).

Species most abundant in Juncus marsh included heavy marsh crab, daggerblade grass shrimp, gulf marsh fiddler crab, and white shrimp (fall) (Fig. 3). Heavy marsh crab was more abundant in Juncus marsh than in edge Spartina alterniflora marsh, where- as fewer striped mullet, daggerblade grass shrimp, brown shrimp, and blue crab occurred in Juncus than edge $S$. alterniflora marsh (Table 3 ).

Nonvegetated areas were dominated by gulf menhaden and brown shrimp in spring and bay anchory and naked goby in fall (Table 3, Fig. 3). Within nonvegetated areas, we found highest mean densities of gulf menhaden, bay anchovy, and naked goby in marsh channels (Table 3 ). Of all the nonvegetated areas, coves contained the highest mean density of brown shrimp in spring. We also collected most Atlantic croaker from coves in spring (Table 3). Marsh ponds had the highest mean density of white shrimp in fall (Table 3). No white shrimp were taken in shallow bay waters (Table 3 ).

Nearly $50 \%$ of the total molluscs collected at East Bay were marsh periwinkle or eastern melampus. Marsh periwinkle was most abundant in inner Spartina alterniflora and Juncus marshes, and most eastern melampus occurred in inner $S$. alterniflora marsh.

\section{Infauna}

Infaunal taxa taken from marsh and shallow water substrates were mainly annelids, insects, and molluscs in upper Galveston Bay and annelids and small crustaceans in East Bay (Table 4). At the upper Galveston Bay location, infaunal densities were greatest in the spring; most numerically dominant taxa were more abundant in nonvegetated areas, although densities of oligochaetes and chironomids were not significantly different between vegetated and nonvegetated areas (Table 4). Among marsh types, edge Spartina alterniflora marsh contained the highest mean densities of most taxa. Edge S. alterniflora and marsh ponds were dominated by chironomids and 2 polychaetes (Capitella capitata and Laeonereis culveri). These 3 taxa also were present, though less abundant, in channels. Channels and coves contained numerous individuals of the polychaete genus Mediomastus. Although we could not identify this taxon to species (because few intact organisms were recovered), most were likely Mediomastus ambiseta, which is one of the most abundant polychaetes in subtidal areas of Galveston Bay (Harper 1992). Oligochaetes and C. capitata also were numerous in coves. Although infaunal densities observed in the other habitat types declined to low values in the fall, densities in the shallow bay were high in fall and consisted mainly of oligochaetes and several taxa of polychaetes (Mediomastus spp., Parandalia ocularis, and Streblospio benedicti) (Table 4).

Most of the numerically dominant taxa at the East Bay location were more abundant in nonvegetated areas than marsh, although oligochaetes and 2 poly. 


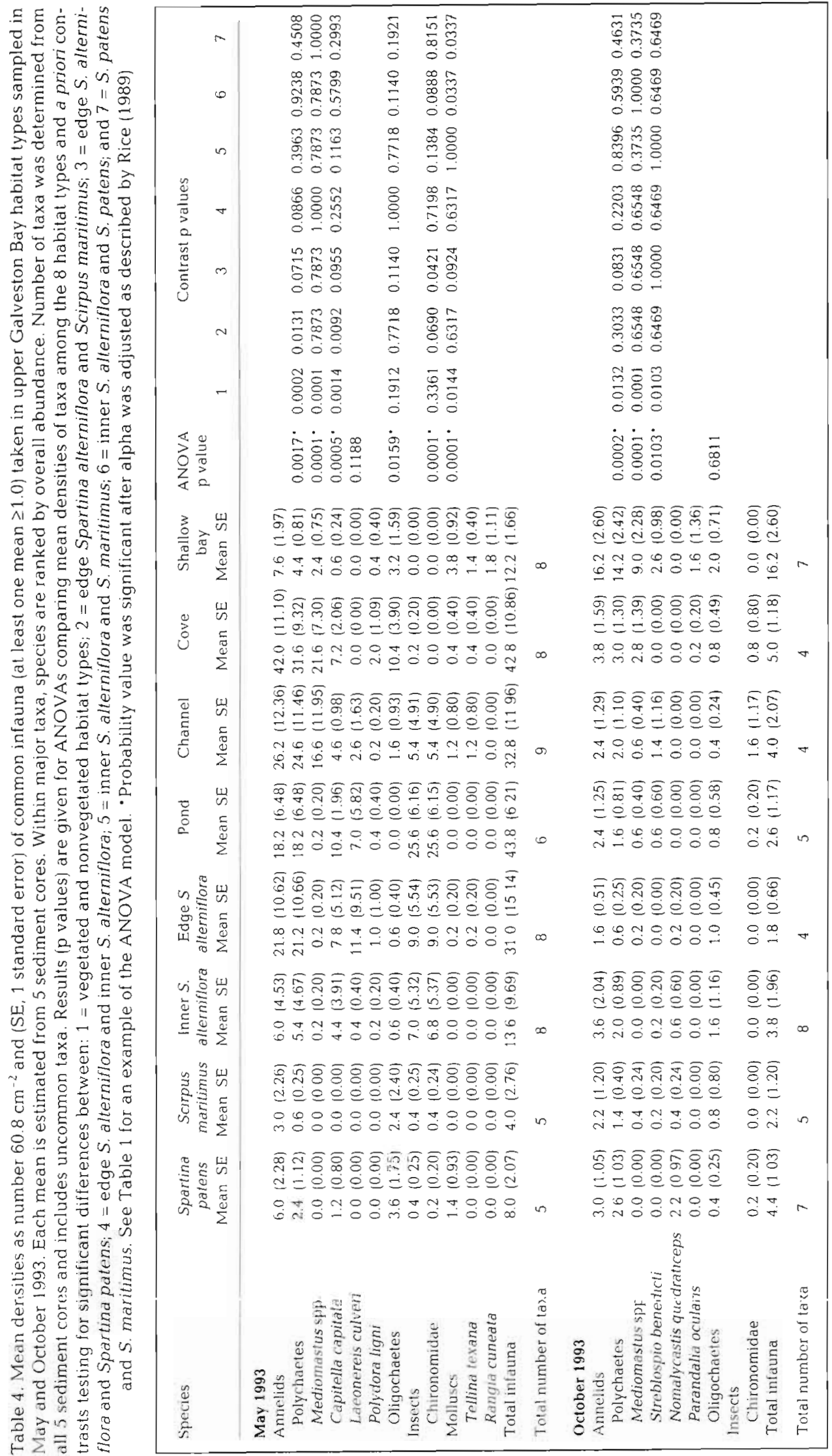


chaetes (Capitella capitata and Fabricia sp.) were most numerous in Spartina alterniflora and Juncus marshes (Table 5). Amphipods (Hargeria rapax and Corophium spp.) and 3 polychaetes (Mediomastus spp., Parandalia ocularis, and Nereis succinea) were most numerous in the shallow bay (Table 5). Mediomastus spp. also dominated the infaunal assemblages in ponds, channels, and coves (Table 5).

\section{Environmental parameters}

At upper Galveston Bay, vegetated habitats had significantly less dissolved oxygen, lower water temperatures, and shallower water depths than nonvegetated areas (Table 6). Turbidity levels were higher in marsh than nonvegetated areas in May, but this pattern was reversed in October. Within vegetated marsh areas, means of most environmental characteristics were not significantly different. However, edge Spartina alterniflora marsh flooded more deeply than S. patens marsh; and inner $S$. alterniflora and $S$. patens marshes had significantly lower dissolved oxygen concentrations than Scirpus marsh in October (Table 6). The average density of plant stems and standing biomass in the marsh types were less in the spring than in the fall at the end of the growing season (Table 6, Fig. 4). In $S$. patens marsh, average stem density was an order of magnitude higher than in other marsh types, and stem densities were significantly greater in this marsh than the other marsh types in both the spring and fall (Fig. 4a). $S$. patens marsh also had significantly higher standing biomass than the other marsh types in the spring (Fig. $4 \mathrm{~b}$ ). In the fall, the standing biomass of $S$. patens was similar to that of the $2 S$. alterniflora marsh types, and these were significantly greater than the Scirpus marsh biomass (Fig. 4b).

At the East Bay location, marsh areas had significantly less dissolved oxygen, lower water temperatures, lower salinity (April only), and shallower water depths than nonvegetated areas (Table 7). Turbidity levels were higher in marsh than nonvegetated areas only in the fall. Some environmental characteristics differed among marsh types as well. For example, inner Spartina alterniflora marsh had significantly lower dissolved oxygen levels than edge S. alterniflora or Juncus marsh in October (Table 7). The average density of plant stems in Juncus marsh was significantly greater than in the 2 Spartina marsh types in both the spring and fall (Table 7, Fig. 5a). Standing biomass did not differ significantly among habitat types in spring (Fig. 5b). However, in fall when plant biomass peaked, Juncus marsh had significantly higher standing biomass than edge $S$. alterniflora marsh (Fig. 5b); the mean standing biomasses of Juncus and inner $S$. alterniflora were not significantly different in fall ( $p>$ $0.05)$.

Flooding durations differed among habitat types in response to differences in surface elevations (Table 8, Fig. 6a). Among marsh types, edge Spartina alterniflora marsh had the lowest surface elevation. In upper Galveston Bay, inner S. alterniflora, Scirpus, and $S$. patens marshes exceeded the elevation of edge $S$. alterniflora marsh by $5.0,6.7$, and $22.0 \mathrm{~cm}$, respectively. The mean flooding duration in 1993 for edge $S$. alterniflora marsh was over $45 \%$, and monthly flooding durations ranged from $26 \%$ in August to $72 \%$ in June (Table 8, Fig 6a). Inner $S$. alterniflora marsh flooded $37 \%$ of the time in 1993, and monthly flooding durations ranged from 18 to $63 \%$. Scirpus marsh was inundated about $34 \%$ of the time (range $=12$ to $62 \%$ ), whereas $S$. patens marsh flooded approximately $13 \%$ of the time (range $=0$ to $32 \%$ ). Nonvegetated areas were submerged for longer periods than marsh (Fig 6b). Shallow bay was inundated $98 \%$ of the time in 1993; whereas marsh channels (87\%), coves (76\%), and ponds (74\%) were flooded less (Fig. 6b).
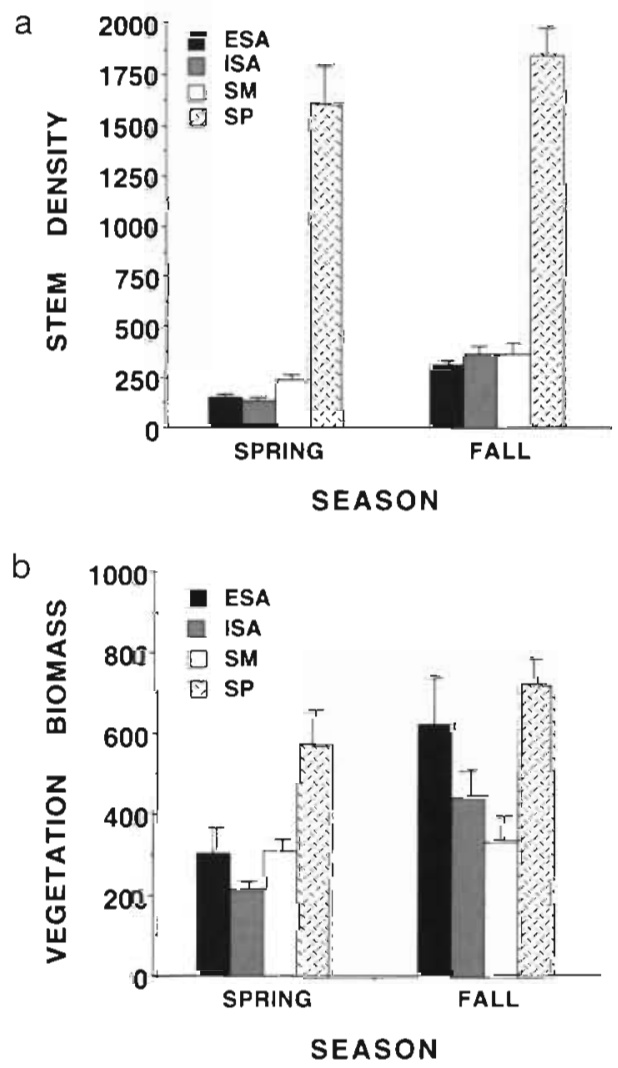

Fig. 4. Average stem densities (plant stems $\mathrm{m}^{-2}$ ) and plant biomasses ( $\mathrm{g}$ dry $w \mathrm{t}^{-2}$ ) of vegetation sampled from marsh in upper Galveston Bay. ESA: edge Spartina alterniflora; ISA: inner Spartina alterniflora; SM: Scirpus maritimus; SP: Spartina patens. Error bars $=1$ standard error (SE). Means and SEs were calculated from 8 samples per habitat type 

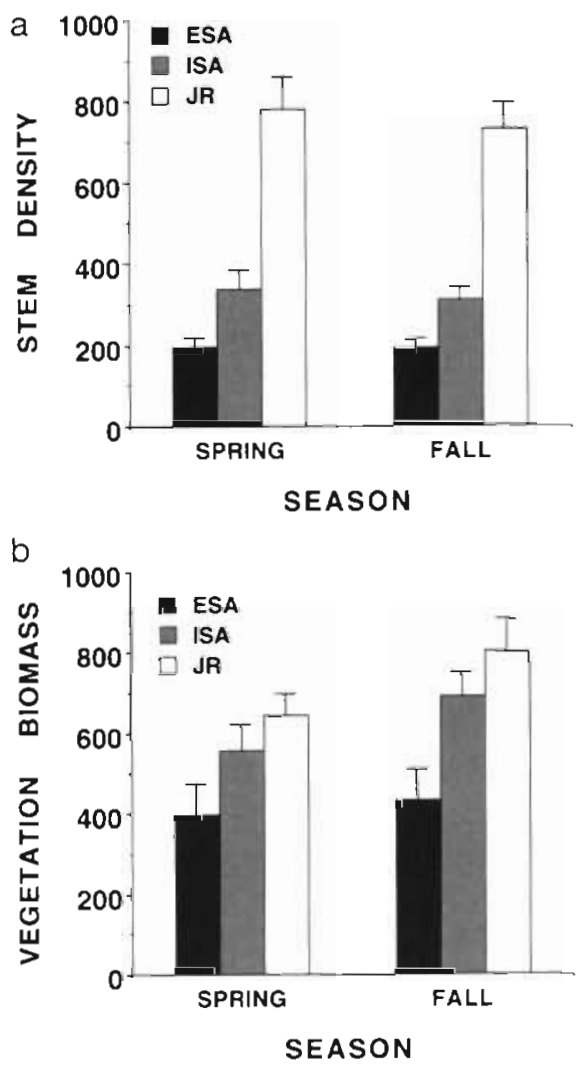

Fig. 5. Average stem densities (plant stems $\mathrm{m}^{-2}$ ) and plant biomasses ( $\mathrm{g}$ dry $\mathrm{wt} \mathrm{m}^{-2}$ ) of vegetation sampled from marsh in East Bay. ESA: edge Spartina alterniflora; ISA: inner Spartina alterniflora; JR: Juncus roemerianus. Error bars = 1 standard error (SE). Means and SEs were calculated from 10 samples per habitat type

At East Bay in 1994, habitats were generally flooded longer than upper Galveston Bay sites in 1993. In 1994, edge Spartina alterniflora marsh at East Bay was submerged $66 \%$ of the time, and flooding durations ranged from $45 \%$ in January to $91 \%$ in October (Fig. 7a). Inner S. alterniflora marsh was inundated $53 \%$ of the time in 1994 (range $=29$ to $85 \%$ ), and Juncus marsh was submerged only $34 \%$ of the time (range $=15$ to $71 \%$ ). The difference in flooding duration between locations (upper Galveston Bay and East Bay) apparently was not due to interannual differences in tide levels. Flooding durations within marsh types were similar in 1993 and 1994 (Table 8). These differences between locations may be the result of differences in the position of the marsh within the tidal frame. The East Bay marsh is located lower in the tidal frame (i.e. the surface elevation is lower relative to Mean Tide Level) than the marsh at upper Galveston Bay (Table 8). Nonvegetated bottom habitats at East Bay were inundated most of the lime in 1994 (Fig. 7b). Shallow bay and cove sites were almost continuously submerged (average flooding durations $>99 \%$ ).

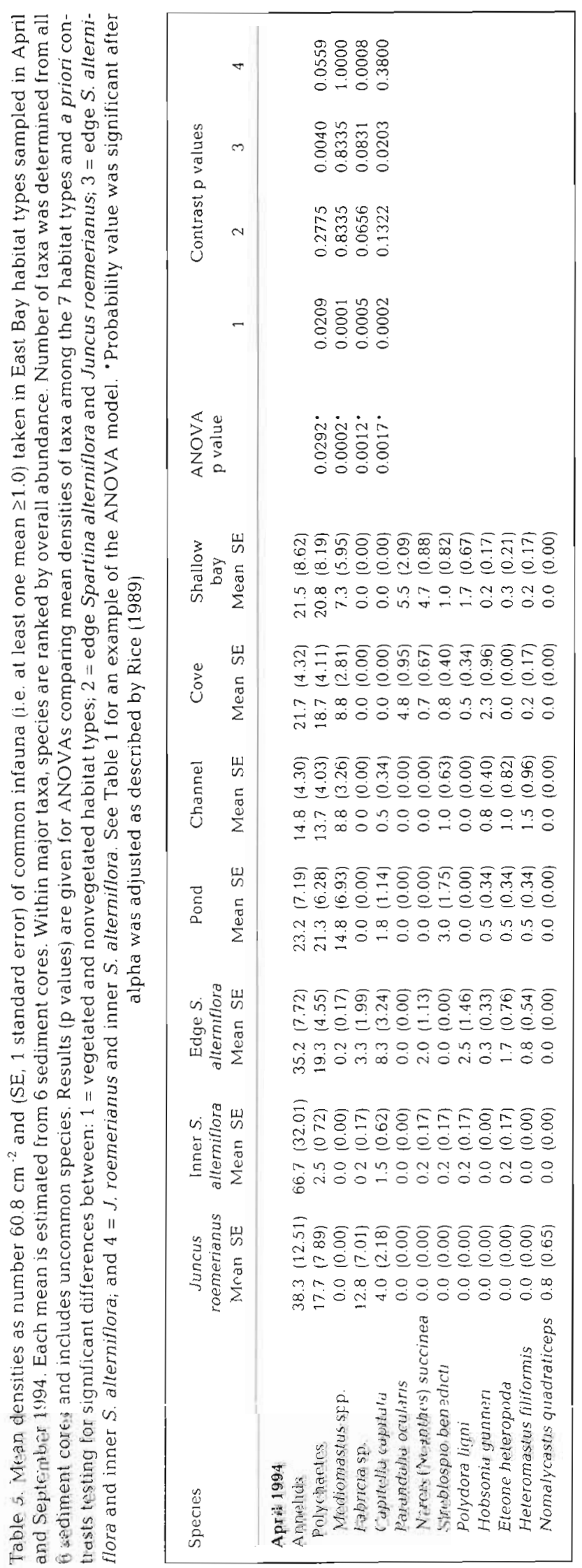




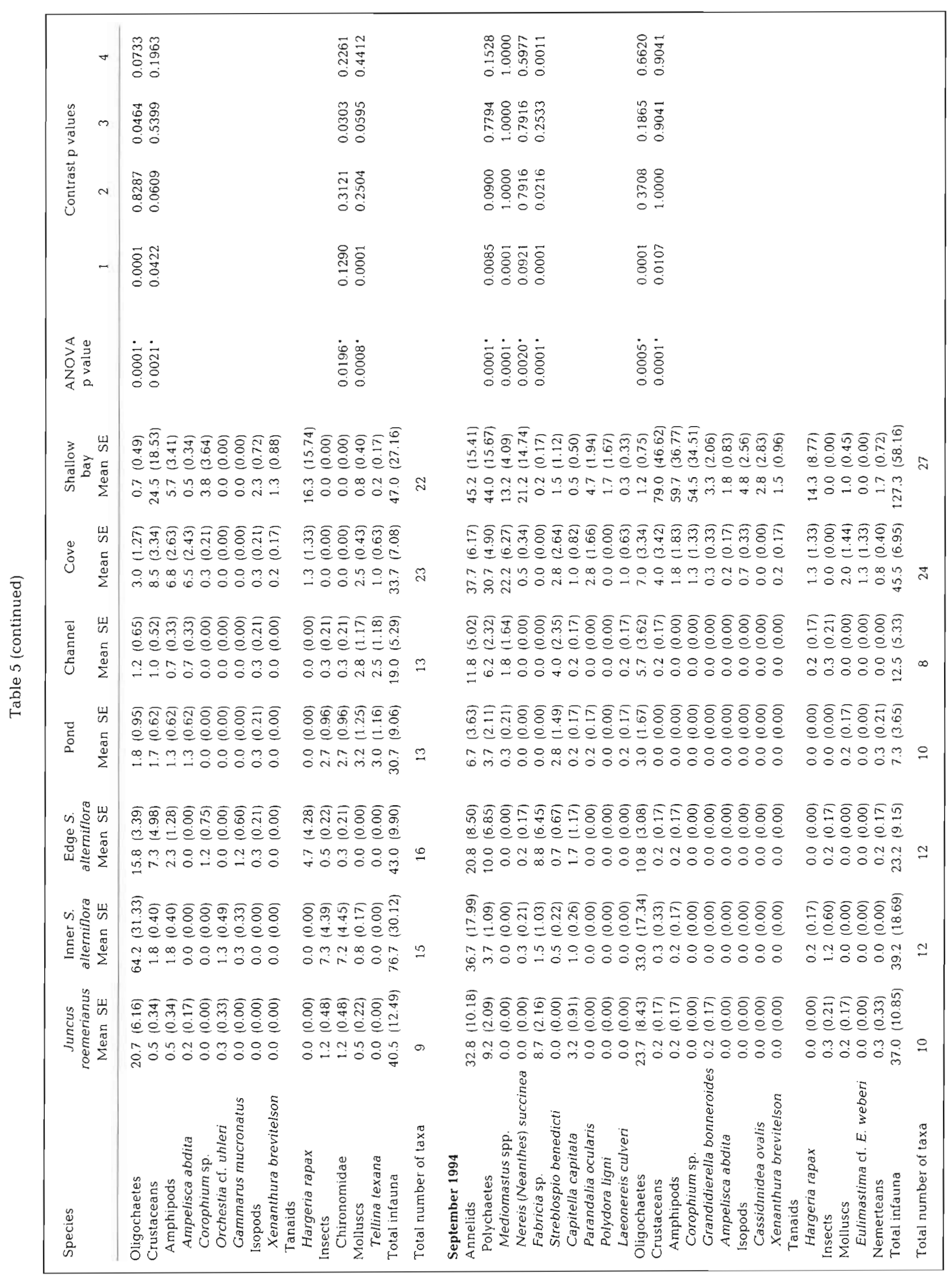


Table 6. Environmental characteristics of upper Galveston Bay habitat types. Mean and (SE, 1 standard error) are given for 8 parameters measured in May and October 1993. Each mean is estimated from 8 samples in each habitat type (exceptions: In May - Turbidity:- Pond [ $\mathrm{n}=2$ ]; Spartina patens, inner Spartina alterniflora, and Scirpus maritimus [ $\mathrm{n}=4$ ]; Channel [ $\mathrm{n}=6$ ]; Cove $[n=7]$; Water depth:- Shallow bay $[n=7]$; Distance to edge:- Cove $[n=6]$; Pond and Shallow bay $[n=7]$; in October - Distance to edge:- Shallow bay $[n=5]$; Channel and Cove $[n=7]$; all other parameters: Shallow Bay $[n=7]]$. Overall probability value for the test of the main effect Habitat was significant after alpha was adjusted as described by Rice (1989). Means of marsh types with the same letter are not significantly different (ANOVA, contrasts, $\mathrm{p}>0.05$ ). Means of marsh types versus nonvegetated habitats are significantly different for all parameters except salinity

\begin{tabular}{|c|c|c|c|c|c|c|c|c|c|}
\hline Parameter & $\begin{array}{c}\text { Spartina } \\
\text { patens } \\
\text { Mean SE }\end{array}$ & $\begin{array}{l}\text { Scirpus } \\
\text { mantimus } \\
\text { Mean SE }\end{array}$ & $\begin{array}{l}\text { Inner } S \text {. } \\
\text { alterniflora } \\
\text { Mean SE }\end{array}$ & $\begin{array}{l}\text { Edge } S . \\
\text { alterniflora } \\
\text { Mean SE }\end{array}$ & $\begin{array}{c}\text { Pond } \\
\text { Mean SE }\end{array}$ & $\begin{array}{l}\text { Channel } \\
\text { Mean SE }\end{array}$ & $\begin{array}{c}\text { Cove } \\
\text { Mean SE }\end{array}$ & $\begin{array}{c}\text { Shallow } \\
\text { bay } \\
\text { Mean SE }\end{array}$ & p value \\
\hline \multicolumn{10}{|l|}{ May 1993} \\
\hline Dissolved oxygen (ppm) & 5.6 a $\{0.34\}$ & $5.9 a(0.47)$ & $5.5 \mathrm{a}(0.46)$ & 6.4 a $(0.18)$ & $6.1(0.52)$ & $6.8(0.46)$ & $7.9(0.27)$ & $9.3(0.12)$ & $0.0001^{\circ}$ \\
\hline Salınity $(\%)$ & $5.1 \mathrm{a}(0.13)$ & $51 \mathrm{a}(0.13)$ & $5.3 \mathrm{a}(0.16)$ & $5.0 \mathrm{a}(0.00)$ & $5.0(0.00)$ & $4.9(0.13)$ & $5.0(0.00)$ & $4.9(0.13)$ & 0.1862 \\
\hline Temperature $\left({ }^{\circ} \mathrm{C}\right)$ & 24.7 a $(0.71)$ & 24.1 a $(0.55)$ & $24.2 \mathrm{a}(0.59)$ & 23.7 a $(0.36)$ & $24.6\{0.46\}$ & $25.7\{0.52\}$ & $26.5(0.47)$ & $27.9(0.08)$ & $0.0001^{\circ}$ \\
\hline Turbidity (FTU) & $312 a\{69.0\}$ & $152 \mathrm{a}(16.7)$ & 194 a (48.3) & $148 \mathrm{a}(14.9)$ & $129(31.5)$ & $123(18.2)$ & $142(39.8)$ & $57(6.5)$ & $0.0004^{\circ}$ \\
\hline Water depth $(\mathrm{cm})$ & $17 b(1.6)$ & $27 \mathrm{ab}(2.4)$ & $26 a b(1,9)$ & $35 \mathrm{a}(4.3)$ & $51(2.0)$ & $70(5.8)$ & $52(8.1)$ & $74(2.1)$ & $0.0001^{\circ}$ \\
\hline Distance to edge $(\mathrm{m})$ & $1.0 \mathrm{a}(0.20)$ & $1.2 \mathrm{a}(0.30)$ & $6.8 \mathrm{~b}(0.60)$ & $0.1 \mathrm{a}(0.10)$ & $6.6\{1.10\}$ & $1.8(0.30)$ & $16.5(5.30)$ & $21.4(3.40)$ & $0.0001^{\circ}$ \\
\hline Vegetation biomass $(g)$ & $653 b(94.6)$ & $362 \mathrm{a}(33.0)$ & $250 a(24.7)$ & $356 a(75.5)$ & & & & & $0.0010^{\circ}$ \\
\hline Stem density (no. $\mathrm{m}^{-2}$ ) & $1603 b(190.3)$ & 237 a $(23.0)$ & $132 \mathrm{a}(16.3)$ & $149 \mathrm{a}\{20.2\}$ & & & & & $0.0001^{\circ}$ \\
\hline \multicolumn{10}{|l|}{ October 1993} \\
\hline Dissolved oxygen (ppm) & $2.3 a(0.27)$ & $5.4 \mathrm{~b}(0.62)$ & $2.6 \mathrm{a}(0.41)$ & $3.1 \mathrm{ab}(1.94)$ & $4.7(0.84)$ & $4.2(0.48)$ & $6.6(0.23)$ & $6.5(0.11)$ & $0.0013^{\circ}$ \\
\hline Salinity $(\%)$ & $18 \mathrm{a}(0.27)$ & $18.3 a(0.16)$ & $18.4 a(0.26)$ & $17.9 \mathrm{a}(0.23)$ & $18.6(0.32)$ & $18.6(0.26)$ & $18.6(0.18)$ & $18.1(0.26)$ & 0.2062 \\
\hline Temperature $\left({ }^{\circ} \mathrm{C}\right)$ & $26.2 \mathrm{a}(0.11)$ & $25.5 a(0.54)$ & 26.4 a $(0.18)$ & $25.8 \mathrm{a}(0.56)$ & $27.2(0.19)$ & $26.7(0.19)$ & $29.0(0.12)$ & $24.9(0.53)$ & $0.0001^{\circ}$ \\
\hline Turbidity (FTU) & 63 a $(16.4)$ & 55 a $(5.3)$ & $44 \mathrm{a}(10.0)$ & 61 a (26.2) & $78(19.7)$ & $60(14.9)$ & $158(16.6)$ & $23(6.1)$ & $0.0001^{\circ}$ \\
\hline Water depth $(\mathrm{cm})$ & $15 \mathrm{~b}(2.6)$ & $20 \mathrm{ab}(3.9)$ & $22 \mathrm{ab}(2.9)$ & 27 a (4.2) & $42(1.2)$ & $62(7.2)$ & $32(3.1)$ & $89\{2.6\}$ & $0.0001^{\circ}$ \\
\hline Distance to edge $\{\mathrm{m}\}$ & $1.5 a(0.30\}$ & $1.2 \mathrm{a}(0.50)$ & $5.9 \mathrm{a}(0.40)$ & $0.2 \mathrm{a}(0.10)$ & $7.0(1.10)$ & $1.8(0.40)$ & $23.4(8.90)$ & $26.7(2.60)$ & $0.0001^{\circ}$ \\
\hline Vegetation biomass (q) & $810 \mathrm{~b}(75.3)$ & 400 a (70.5) & $596 \mathrm{~b}(90.4)$ & $849 \mathrm{~b}(154.8)$ & & & & & $0.0017^{\circ}$ \\
\hline Stem density (no. $\mathrm{m}^{-2}$ ) & $1842 b(143.2)$ & 357 a $(59.5)$ & 358 a (37.5) & $308 a(20.9\}$ & & & & & $0.0001^{\circ}$ \\
\hline
\end{tabular}

Although flooded less than shallow bay and cove habitats, marsh ponds $(95 \%)$ and channels $(89 \%)$ were also submerged for long periods (Fig. $7 \mathrm{~b}$ ).
Results of the discriminant analysis clearly show that we can statistically separate the habitat types we sampled in our study based on environmental characteris-

Table 7. Environmental characteristics of East Bay habitat types. Mean and (SE, 1 standard error) are given for 8 parameters measured in April and September 1994. Each mean is estimated from 10 samples in each habitat type (exceptions: in April - Water temperature:- Shallow bay, [ $\mathrm{n}=91$ and Dissolved oxygen:- Juncus roemerianus marsh [ $\mathrm{n}=9]$ ). "Probability value for the test of the main effect Habitat was significant after alpha was adjusted as described by Rice (1989). Means of marsh types with the same letter are not significantly different (ANOVA, contrasts, $p>0.05$ ). Means of marsh types vs nonvegetated habitat types are significantly different for all parameters except turbidity in April and salinity and temperature in September

\begin{tabular}{|c|c|c|c|c|c|c|c|c|}
\hline Parameter & $\begin{array}{c}\text { Juncus } \\
\text { romerianus } \\
\text { Mean SE }\end{array}$ & $\begin{array}{l}\text { Inner S. } \\
\text { alterniflora } \\
\text { Mean SE }\end{array}$ & $\begin{array}{l}\text { Edge } 5 \text {. } \\
\text { alterniflora } \\
\text { Mean SE }\end{array}$ & Mean SE & $\begin{array}{l}\text { Channel } \\
\text { Mean SE }\end{array}$ & Mean SE & $\begin{array}{c}\text { Shallow } \\
\text { bay } \\
\text { Mean SE }\end{array}$ & $p$ value \\
\hline \multicolumn{9}{|l|}{ April 1994} \\
\hline Dissolved oxygen (ppm) & $6.5 \mathrm{~b}(0.27)$ & $4.9 a(0.32)$ & $5.9 b(0.28)$ & $56\{0.20\}$ & $58\{0.32\}$ & $7.3(0.23)$ & $7.7 !(0.06)$ & $0.0001^{\circ}$ \\
\hline Salinity $(\%)$ & 11.1 a $(0.10)$ & $11.6 \mathrm{a}(0.22)$ & 11.5 a $(0.50)$ & $12.2\{0.42\}$ & $11.9(0.38)$ & $14.6(0.16)$ & $13.3(0.58)$ & $0.0001^{\circ}$ \\
\hline Temperature $\left({ }^{\circ} \mathrm{C}\right.$ ) & $25.8 \mathrm{ab}(0.19)$ & $26.2 b(0.31)$ & $25.3 \mathrm{a}(0.26)$ & $25.1(0.11)$ & $26.3(0.25)$ & $27.5(0.20)$ & $26.2(0.12)$ & $0.0001^{\circ}$ \\
\hline Turbidity (FTU) & $25.9 \mathrm{a}(2.3)$ & $31.8 \mathrm{a}(3.4)$ & $40 \mathrm{a}(12.3)$ & $23(3.1)$ & $27(3.4)$ & $22(3.2)$ & $16(2.1)$ & 0.0791 \\
\hline Water depth $(\mathrm{cm})$ & $410(2.2)$ & $29 a(1.6)$ & $38 \mathrm{~b}(3.4)$ & $67(18)$ & $63(1.9\}$ & 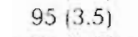 & $102(2.2)$ & $0.0001^{\circ}$ \\
\hline Distance to edge $(\mathrm{m})$ & $0.2 \mathrm{a}(0-10)$ & $6.5 b(0.30)$ & $0.1 \mathrm{a}\{0.10\}$ & $13.1(4.10)$ & $14(0.30)$ & $16.4(3.40)$ & $15.3(1.60)$ & $00001^{\prime}$ \\
\hline Vegetation biomass $(g)$ & $532 a(67.1)$ & 516 a $(60.0)$ & 397 a $\{79.6\}$ & & & & & 0.3381 \\
\hline Stem density $\left\{n o \cdot \mathrm{m}^{-2}\right\}$ & 616617701 & $253 a(30.8)$ & $1960(22.5)$ & & & & & $0.0001^{\circ}$ \\
\hline \multicolumn{9}{|l|}{ September 1994} \\
\hline Igissoiveri oxygen (pyuj) & $420\{0.23\}$ & $4.2=\{0.38\}$ & Afa ( 028$)$ & 4.810 .331 & 4.610 .331 & $5.6(0.15)$ & $6.1(0.18)$ & $0.0001^{*}$ \\
\hline Salinity $(\%)$ & $15.0 \mathrm{a}(0.00)$ & 15.7 a $\{0.40\}$ & $16.1 \mathrm{~d}(0.38)$ & $15.9(0.46)$ & $15.7(0.45)$ & $15.1(0.28)$ & $15.7(0.60)$ & 0.43 .40 \\
\hline Temperature f $\mathrm{C}$ ' & $27.8 \mathrm{a}(0.37)$ & $28.3 \mathrm{a}(0.34)$ & $28.2 a(0.34)$ & $28.9(0.40)$ & $28.5(0.57)$ & $28.6(0.22)$ & $26.6(0.33)$ & $0.0018^{*}$ \\
\hline Turbidity (FTU) & 23 a $(1.5)$ & $29 a b(5.7)$ & $40 \mathrm{~b}(6.4)$ & 2313.81 & $14(3,3)$ & $15(1.2)$ & $24(7.1)$ & $0.0043^{\circ}$ \\
\hline Water depth $(\mathrm{cm})$ & $31 \mathrm{a} \mid 1.0\}$ & 24 a (2.5) & $32 \mathrm{a}(4.0)$ & $54(3.3)$ & $52(9.1)$ & $87(2.1)$ & $75152)$ & $0.0001^{\circ}$ \\
\hline Distance to edge (m) & $0.6 a(0,10)$ & $5.7 \mathrm{~b}(0.20)$ & $0.7 \mathrm{a}(0.20)$ & $5.8(2.40\}$ & $1.1(0.20)$ & $107(1.70)$ & $9.5(1.00\}$ & $0.0001^{\circ}$ \\
\hline Vegetation biomass $(g)$ & $721 b(82.5)$ & $568 \mathrm{~b} \mid 60.3\}$ & 431 a $(75.3)$ & & & & & $0.0215^{\circ}$ \\
\hline Stem density (no. $\mathrm{m}^{2}$ ) & $664 b(72.6)$ & 289 a $(33.8)$ & $186 \mathrm{a}(21.5)$ & & & & & $0.0001^{\circ}$ \\
\hline
\end{tabular}


Table 8. Mean elevation and flooding durations of each habitat type sampled at upper Galveston Bay in 1993 and East Bay in 1994. Elevations are based on a Mean Tide Level (MTL) of $182.9 \mathrm{~cm}(6.0 \mathrm{ft})$ for the Morgans Point tide station and an adjusted MTL of $130.1 \mathrm{~cm}$ ( $4.3 \mathrm{ft}$ ) for East Bay that was calculated from the MTL at the Pier 21 tide station using an equation from Minello \& Webb (1997). Each mean is estimated from 16 (except Shallow bay = 14) and 20 samples in each habitat type at upper Galveston Bay and East Bay. respectively

\begin{tabular}{|c|c|c|c|}
\hline \multirow[t]{2}{*}{ Habitat type } & \multirow{2}{*}{$\begin{array}{l}\text { Elevation } \\
\text { MTL }(\mathrm{cm})\end{array}$} & \multicolumn{2}{|c|}{ Flooding durations ( $\%$ ) } \\
\hline & & 1993 & 1994 \\
\hline \multicolumn{4}{|l|}{ Upper Galveston Bay } \\
\hline Shallow Bay & -52.0 & 97.5 & 97.9 \\
\hline Cove & -17.7 & 76.2 & 80.9 \\
\hline Channel & -26.7 & 86.8 & 89.5 \\
\hline Pond & -12.8 & 74.4 & 74.9 \\
\hline Edge $S$. alterniflora & 4.4 & 45.6 & 45.8 \\
\hline Inner $S$ alterniflora & 9.4 & 37.4 & 35.8 \\
\hline Scirpus maritimus & 11.1 & 34.3 & 32.9 \\
\hline Spartina patens & 26.4 & 12.9 & 9.7 \\
\hline \multicolumn{4}{|l|}{ East Bay } \\
\hline Shallow Bay & -58.3 & 99.7 & 99.8 \\
\hline Cove & -53.1 & 99.3 & 99.4 \\
\hline Channel & -31.7 & 95.6 & 88.5 \\
\hline Pond & -31.4 & 95.6 & 94.9 \\
\hline Edge $S$. alterniflora & -6.5 & 66.6 & 66.2 \\
\hline Inner $S$. alterniflora & 0.8 & 50.2 & 52.7 \\
\hline Juncus roemerianus & 9.1 & 31.4 & 34.3 \\
\hline
\end{tabular}

tics (Figs. $8 \& 9$ ). The multivariate model used to discriminate among the 9 habitat types was highly significant (Wilks' lambda $=0.018, \mathrm{df}=64,1275, \mathrm{p}<0.0001$ ). The first 2 canonical variates in the model were responsible for $96 \%$ of the separation (Fig. 8), and the predictor variables having the highest standardized discriminant weights were stem density (weights: first canonical variate $=-2.274$, second canonical variate $=$ 1.405 ) and water depth (weights: first canonical variate $=0.589$, second canonical variate $=1.390$ ). The model accurately classified most habitat types (median accuracy $=90 \%$ ), although the accuracy of the model was relatively low in classifying marsh channel (18\%) and Scirpus $(33 \%)$ sites. Many channel (58\%) and Scirpus $(42 \%)$ sites were incorrectly classified as pond and edge Spartina alterniflora sites, respectively.

Marsh types also could be clearly separated using discriminant analysis (Wilks' lambda $=0.008, \mathrm{df}=$ $32,367, p<0.0001)$. In this analysis, the first 2 canonical variates were responsible for $98 \%$ of the separation among habitat types (Fig. 9), and the predictor variables with the highest standardized weights were distance to edge (3.316) and water depth $(-0.425)$ in the first canonical variate and stem density (2.245) in the second canonical variate. Marsh sites were accurately classified for $94,97,100,100$, and $33 \%$ of edge Spar- tina alterniflora, inner $S$. alterniflora, Juncus, S. patens, and Scirpus sites, respectively. Fifty percent of the Scirpus sites we sampled were incorrectly classified as edge $S$. alterniflora sites.

\section{Environmental characteristics and decapod and fish densities}

The canonical analysis for the relationship between densities of decapod crustaceans and fishes and environmental characteristics of habitat types was statistically significant (Wilks' lambda $=0.059$, df $=144,1559$, $p<0.0001)$. The first canonical variate pair showed that $60 \%$ of the variance in animal densities was explained by environmental variables. In this equation, high densities of Atlantic croaker and blackcheek tonguefish and low densities of gulf marsh fiddler crab were associated with deep water, high turbidity levels,
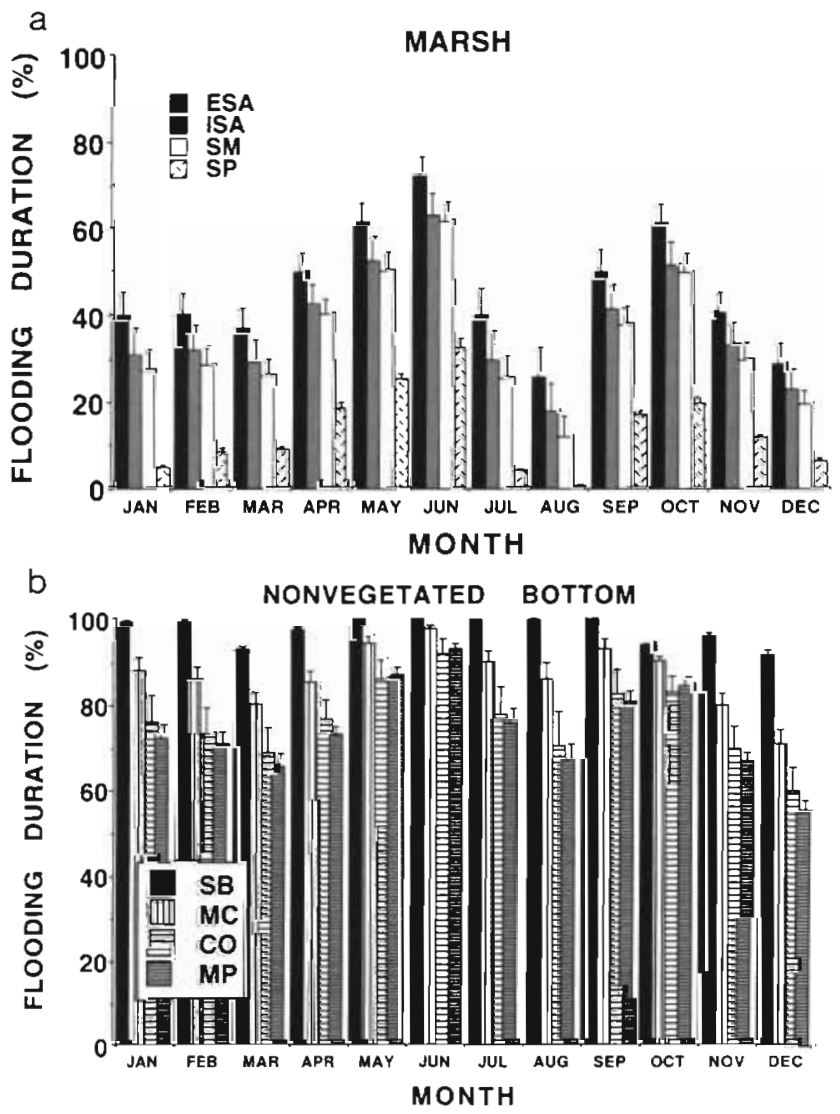

Fig. 6. Average monthly flooding durations ([hours habitat type inundated/total hours in month] $\times 100$ ) of marsh and nonvegetated areas in upper Galveston Bay. Error bars = 1 standard error (SE). ESA: edge Spartina alterniflora; ISA: inner Spartina alterniflora; SM: Scirpus maritimus; SP: Spartina patens; SB: shallow bay; MC: marsh channels; CO: coves; MP: marsh ponds. Means and SEs were calculated from 16 samples from each habitat type (except shallow bay $=14$ ) 

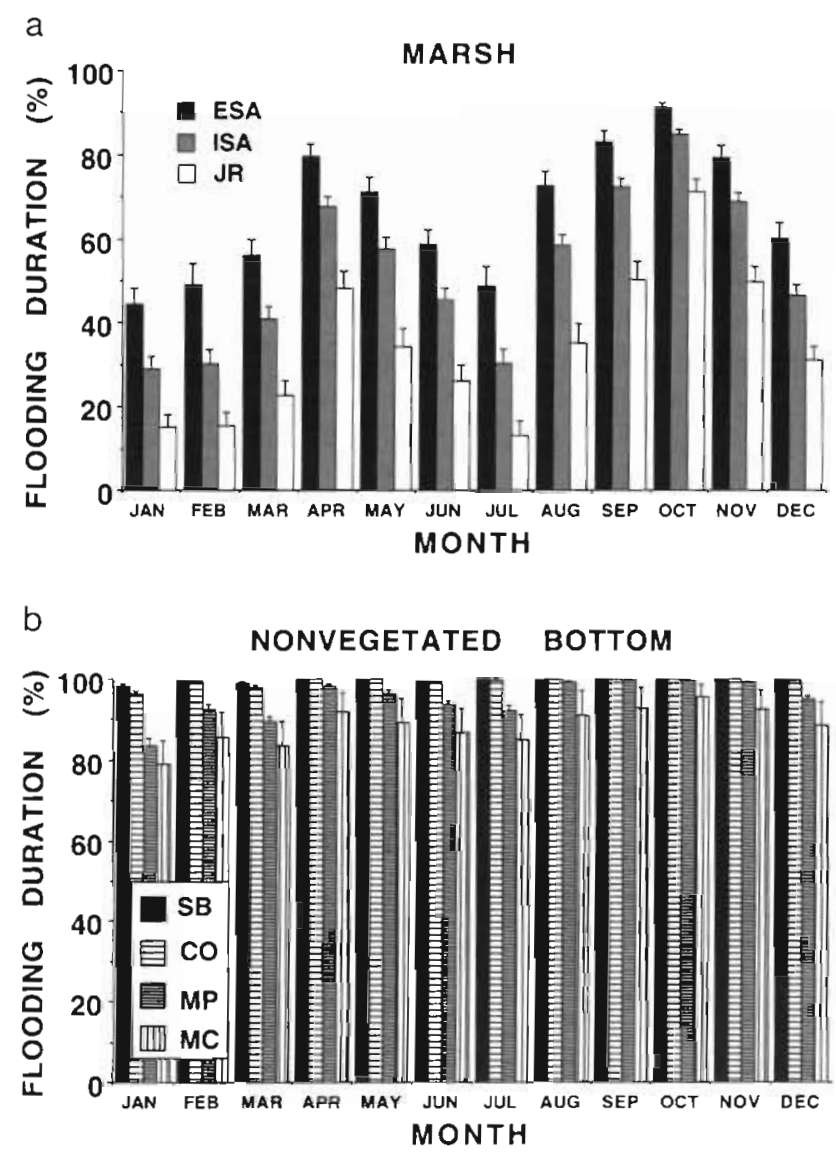

Fig. 7. Average monthly flooding durations (lhours habitat type inundated/total hours in month] $\times 100$ ) of marsh and nonvegetated areas in East Bay. ESA: edge Spartina alterniflora; ISA: inner Spartina alterniflora; JR: Juncus roemerianus; SB: shallow bay; CO: coves; MP: marsh ponds; MC: marsh channels. Error bars $=1$ standard error (SE). Means and SEs were calculated from 20 samples from each habitat type

and high salinity (Table 9). The second variate pair explained an additional $23 \%$ of the variance; in this equation, high densities of white shrimp and blue crab and low densities of brown shrimp were associated with high values for salinity, elevation, and temperature. This second equation is influenced by a strong seasonal signal. Relatively high temperature and salinity occurred in the fall and coincided with high densities of white shrimp and relatively low densities of brown shrimp. White shrimp were not collected in spring. The high canonical weight given to elevation in the second variate pair is an indication that higher densities of white shrimp and blue crab were taken at marsh sites than in nonvegetated areas; marsh sites were generally higher in elevation than nonvegetated areas.

The canonical analysis for the relationship between densities of decapod crustaceans and fishes at marsh sites and environmental parameters also was statisti-

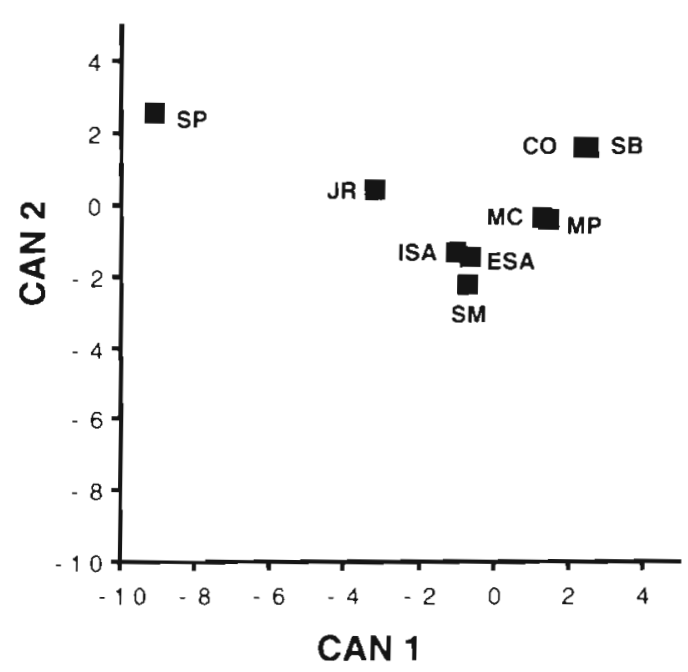

Fig. 8. Separation of habitat types using environmental characteristics. This plot of class means from the discriminant model shows the relative position of each habitat type along the canonical axes. Heavily weighted variables in both canonical variates were water depth and stem density. ESA: edge Spartina alterniflora; ISA: inner Spartina alterniflora; SM: Scirpus maritimus; SP: Spartina patens; JR: Juncus roemerianus; MP: marsh ponds; $\mathrm{MC}$ : marsh channels; $\mathrm{CO}$ : coves; SB: shallow bay

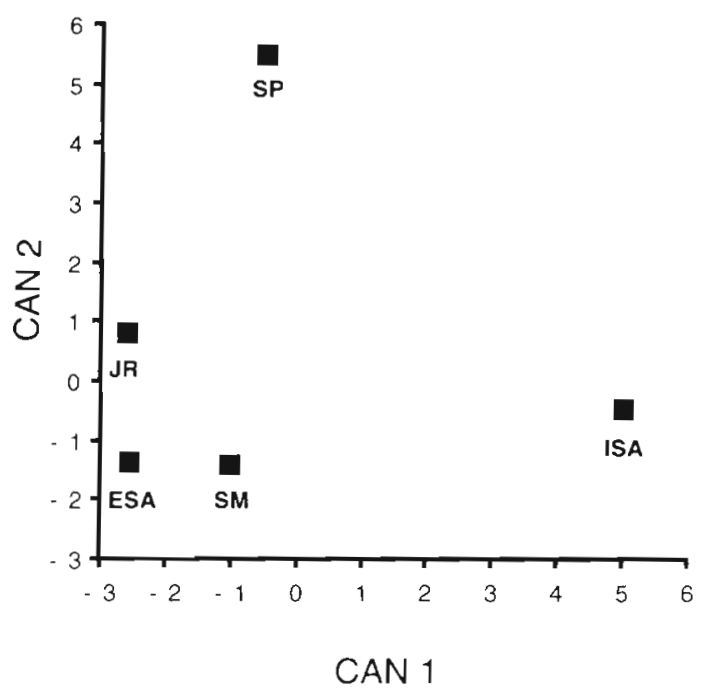

Fig. 9. Separation of marsh types by environmental characteristics. This plot of class means from the discriminant model shows the relative position of each marsh type along the canonical axes. Heavily weighted variables were distance to edge and water depth in CAN 1 and stem derisity in CAN 2. ESA: edge Spartina alterniflora; ISA: inner Spartina alterniflora; SM: Scirpus maritimus; SP: Spartina patens; JR: Juncus rocmerianus

cally significant (Wilks' lambda $=0.021$, df $=112,636$, $\mathrm{p}<0.0001)$. The first canonical variate pair showed that $73 \%$ of the variance in animal densities within marsh was explained by environmental variables. In 
this equation, high densities of brown shrimp, heavy marsh crab, naked goby, and daggerblade grass shrimp were associated with low elevation and small values of distance to edge (Table 10 ). The second variate pair explained an additional $15 \%$ of the variance; in this equation, high densities of white shrimp and low densities of brown shrimp were associated with high temperature, high salinity, and low values of distance to edge. This second equation is influenced by a strong seasonal signal that masked the importance of elevation in explaining the occurrence of white shrimp when both seasons were combined into 1 analysis. When the analysis was repeated using only fall data, the relationship between animal densities and environmental variables was significant (Wilks' lambda = $0.021, \mathrm{df}=88,291, \mathrm{p}<0.0001$ ), and the results indicate that high densities of white shrimp and other species were associated with low elevation and low values of distance to edge. In this analysis, high positive standardized canonical weights for the variables white

Table 9. Standardized canonical weights of potential relationships between animal densities and environmental characteristics of habitat types. Weights are shown only when absolute values exceed 0.250 . First and second variate pairs explained 60 and $23 \%$ of the variance, respectively. In this analysis, we included data from all habitat types, both locations, and both seasons. Number of cases $=236 ; 31$ observations were omitted in the analysis because of missing data

\begin{tabular}{|c|c|c|c|}
\hline \multirow{2}{*}{$\begin{array}{l}\text { Variable } \\
\text { Set }\end{array}$} & \multirow[t]{2}{*}{ Variable } & \multicolumn{2}{|c|}{ Canonical variate pairs } \\
\hline & & First & Second \\
\hline \multirow[t]{8}{*}{ First } & Salinity & 0.320 & 0.715 \\
\hline & Temperature & & 0.407 \\
\hline & Dissolved oxygen & & \\
\hline & Turbidity & 0.379 & \\
\hline & Distance to edge & & \\
\hline & Depth & 0.993 & \\
\hline & Stem density & & \\
\hline & Elevation & & 0.498 \\
\hline \multirow[t]{17}{*}{ Second } & Gulf menhaden & & \\
\hline & Atlantic croaker & 0.328 & \\
\hline & Striped mullet & & \\
\hline & $\begin{array}{l}\text { Spot } \\
\text { Gulf killifish }\end{array}$ & & \\
\hline & Blackcheek tonguefish & 0.268 & \\
\hline & Naked goby & & \\
\hline & Darter goby & & \\
\hline & Sheepshead minnow & & \\
\hline & Bay anchovy & & \\
\hline & Daggerblade grass shrimp & & \\
\hline & Brown shrimp & & -0.471 \\
\hline & Gulf marsh fiddler crab & -0.508 & \\
\hline & Blue crab & & 0.255 \\
\hline & Heavy marsh crab & & \\
\hline & White shrimp & & 0.524 \\
\hline & Marsh grass shrimp & & \\
\hline & Squareback marsh crab & & \\
\hline
\end{tabular}

Table 10. Standardized canonical weights of potential relationships between animal densities and environmental characteristics of marsh habitat types. Weights are shown only when absolute values exceed 0.250 . First and second variate pairs explained 73 and $15 \%$ of the variance, respectively. Only data from marsh samples were used in this analysis (both locations and both seasons were included). Number of cases $=111 ; 13$ observations were omitted in the analysis because of missing data

\begin{tabular}{|c|c|c|c|}
\hline \multirow{2}{*}{$\begin{array}{l}\text { Variable } \\
\text { Set }\end{array}$} & \multirow{2}{*}{ Variable } & \multicolumn{2}{|c|}{ Canonical variate pairs } \\
\hline & & First & Second \\
\hline \multirow[t]{8}{*}{ First } & Salinity & -0.261 & 0.294 \\
\hline & Temperature & & 0.794 \\
\hline & Dissolved oxygen & & \\
\hline & Turbidity & & \\
\hline & Distance to edge & -0.603 & -0.347 \\
\hline & Depth & 0.288 & \\
\hline & Stem density & & \\
\hline & Elevation & -0.416 & \\
\hline \multirow[t]{14}{*}{ Second } & Gulf menhaden & & \\
\hline & Striped mullet & & \\
\hline & Gulf killifish & & \\
\hline & Naked goby & 0.253 & \\
\hline & Darter goby & & \\
\hline & Sheepshead minnow & & \\
\hline & Daggerblade grass shrimp & $\mathrm{p} \quad 0.280$ & \\
\hline & Brown shrimp & 0.370 & -0.466 \\
\hline & Gulf marsh fiddler crab & -0.315 & \\
\hline & Blue crab & & \\
\hline & Heavy marsh crab & 0.453 & \\
\hline & White shrimp & & 0.450 \\
\hline & Marsh grass shrimp & & \\
\hline & Squareback marsh crab & & \\
\hline
\end{tabular}

shrimp (0.290), heavy marsh crab (0.283), darter goby (0.249), and naked goby (0.245) were associated with high negative weights for the variables distance to edge $(-0.539)$ and elevation $(-0.414)$.

\section{DISCUSSION}

Our study allows unbiased comparisons of the use of marsh and shallow nonvegetated bottom by decapod crustaceans and fishes in Galveston Bay because we sampled all areas at similar water levels using quantitative methods (Rozas \& Minello 1997). Our results show that no single habitat type was consistently selected over others by all species, and no species used only one habitat type exclusively. Nonetheless, most species of nekton frequently taken on the marsh surface were concentrated in low marsh located at the marsh-water interface. Thus, for these species, apparent habitat selection within emergent marsh was influenced most by 2 factors: marsh elevation and the proximity of the marsh to open-water areas (Zimmerman \& 
Minello 1984, Rozas 1993, Rozas \& Reed 1993, Peterson \& Turner 1994). In our study, high densities of brown shrimp, white shrimp (fall), daggerblade grass shrimp, naked goby, and darter goby (fall) were strongly associated with low, shoreline marsh sites.

One of the major differences among habitat types in our study was elevation. The mean elevation of Spartina patens marsh and Juncus marsh exceeded that of edge $S$. alterniflora marsh by 22 and $16 \mathrm{~cm}$, respectively. The effect of elevation in our results was evident from differences in nekton use between edge $S$. alterniflora marsh and these 2 high marsh types ( $S$. patens and Juncus). In our study, striped mullet, daggerblade grass shrimp, white shrimp, and blue crab appeared to select edge $S$. alterniflora marsh over high $S$. patens marsh, whereas gulf killifish was significantly more abundant in $S$, patens marsh. Striped mullet, daggerblade grass shrimp, brown shrimp, and blue crab also were more numerous in edge $S$. alterniflora marsh than Juncus marsh. Similarly, in a previous study, brown shrimp and white shrimp seemed to prefer low S. alterniflora marsh, whereas gulf killifish and diamond killifish appeared to favor high Distichlis spicata marsh over low S. alterniflora marsh (Rozas \& Reed 1993). In another study, densities of daggerblade grass shrimp and brown shrimp were 1.2 to 4.3 times higher on low than high $S$. alterniflora marsh, but elevation did not seem to affect the abundance of white shrimp (Minello et al. 1994). Although apparently not the preferred habitat type of these organisms, high marsh in our study was exploited by several species of economic importance. Juncus marsh, in particular, contained modest densities of brown shrimp $\left(>3 \mathrm{~m}^{-2}\right.$ in spring) and blue crab (>1 $\mathrm{m}^{-2}$ in fall) and relatively high densities of white shrimp $\left(>12 \mathrm{~m}^{-2}\right.$ in fall). The highest elevation sites we sampled, within $S$. patens marsh, contained modest densities of brown shrimp (>3 $\mathrm{m}^{-2}$ in spring) and blue crab $\left(1 \mathrm{~m}^{-2}\right.$ in fall).

We examined how habitat selection was affected by the proximity of a marsh to open water (i.e. the edge effect) by comparing animal densities in Scirpus marsh and inner Spartina alterniflora marsh. Although others have examined the edge effect within $S$. alterniflora marsh (Peterson \& Turner 1994, Minello et al, 1994, Minello \& Webb 1997), elevation and proximity to marsh edge were confounded in these studies. Elevation within a $S$. alterniflora marsh generally increases with distance from the shoreline. For example, in our study, the mean elevation of inner $S$. alterniflora marsh was 5 to $7 \mathrm{~cm}$ higher than edge $S$. alterniflora marsh. In contrast, the mean elevation of inner $S$. alterniflora marsh was slightly less $(1.7 \mathrm{~cm})$ than that of Scirpus marsh; therefore, a comparison of nekton densities between these 2 marsh types (inner $S$, alterniflora marsh and Scirpus marsh) should be a conservative test of the edge effect. Even though these 2 habitat types were separated laterally by only a few meters and they had similar elevations, we found significant differences in animal densities between marsh types. In our study, gulf killifish and striped mullet were more numerous in inner $S$. alterniflora marsh, but brown shrimp in spring and daggerblade grass shrimp, white shrimp, and blue crab in fall were significantly more abundant in Scirpus marsh. We found even more differences in animal densities between marsh types when we compared inner $S$. alterniflora marsh and edge $S$. alterniflora marsh. We believe that this result is a response to a combination of the edge and elevation effects. Peterson \& Turner (1994) found that resident marsh species (mostly grass shrimp and killifishes) used inner $S$. alterniflora marsh, and most other nekton was concentrated in marsh within $3 \mathrm{~m}$ of the waters edge. In both natural and created marshes of Galveston Bay, brown shrimp (spring) and blue crab (fall) were significantly more abundant in edge than inner $S$. alterniflora marsh (Minello \& Webb 1997). Because many fishery species prefer marsh edge, increasing this habitat in solid stands of $S$. alterniflora marsh should enhance its habitat value and cause a substantial increase in its use by these species. Constructing channels in a transplanted $S$. alterniflora marsh increased densities of brown shrimp and white shrimp near the channels by a factor of 4.6 to 13 (Minello et al. 1994). Adding channels also significantly raised the densities of polychaete worms and daggerblade grass shrimp in the marsh edge. These animals are an important food of nekton predators such as small fishes, blue crab, and brown shrimp (Harrington \& Harrington 1961, Gleason \& Wellington 1988, Minello et al. 1989, Thomas 1989, McTigue \& Zimmerman 1991).

Distributions of decapod crustaceans and fishes also may be affected by differences in structural complexity of vegetation among habitat types. Plant stem density and standing biomass in our study area generally increased with marsh surface elevation. Predatory fishes and decapod crustaceans may be attracted to sparse vegetation if foraging success is greater there than in dense vegetation. The relatively sparse vegetation of Spartina alterniflora and Scirpus marshes may have provided more foraging surface than nonvegetated areas, yet may have interfered less with movement and foraging activity than dense $S$. patens or Juncus roemerianus vegetation (Vince et al. 1976, Van Dolah 1978, West \& Williams 1986).

The marsh surface and contiguous shallow nonvegetated areas generally supported higher densities of fishes and decapod crustaceans than the nearby shallow bay. Few of the dominant species collected in our study were abundant in shallow bay waters, although the shallow bay occasionally had densities of gulf men- 
haden and bay anchovy similar to those in nonvegetated areas contiguous with marsh.

In nonvegetated areas, water depth and proximity to vegetation may influence nekton densities. Predation risk is high in deep, nonvegetated areas, especially in Gulf coast estuaries (Heck \& Coen 1995). Open bay waters were usually deeper than the other areas we sampled. Mean water depth in the shallow bay was always significantly greater than the average water depths of the marsh surface; it was greater than all other habitat types in fall. In the absence of submerged aquatic vegetation, small fishes and decapod crustaceans may select shallow water to avoid large natant predators (Baltz et al. 1993, Ruiz et al. 1993, Miltner et al. 1995, Kneib 2000). In a study of a subestuary of Chesapeake Bay, Ruiz et al. (1993) found that several small species including daggerblade grass shrimp, naked goby, and 2 killifishes were significantly more abundant in shallow water $(<70 \mathrm{~cm})$, and the proportion of small juvenile blue crabs decreased with depth. They attributed this habitat segregation by depth to predator avoidance by small vulnerable nekton. Known predators (e.g. large spot, Atlantic croaker, and blue crab) were often more abundant in waters $>70 \mathrm{~cm}$, and the mortality rates of tethered claggerblade grass shrimp, killifish, and small blue crabs significantly increased with depth (Ruiz et al. 1993). Submerged vegetation was absent from our study area, and the shallow water of marsh ponds, channels, and coves may have afforded some protection from large natant predators. In addition, animals in nonvegetated areas adjacent to marsh have access to the nearby emergent marsh vegetation when it floods, which would provide protection as well (Minello \& Zimmerman 1983, Minello et al. 1989, Minello 1993). Highest densities of 15 abundant species in nonvegetated areas were collected near the marsh edge, and Baltz et al. (1993) attributed this pattern to the protection provided by both the shallow water and flooded Spartina alterniflora at the marsh-water interface.

The paucity of available prey in the shallow bay may also have contributed to the low densities of most nekton predators. In Galveston Bay, infaunal densities generally peak in spring (between February and May) and decline to a low level in fall (October and $\mathrm{No}$ vember); however, a second peak may occur in the fall (Harper 1992, Whaley 1997). In our study during spring, average total infaunal densities in the shallow bay were lower than those in both Spartina alterniflora marsh types and other nonvegetated areas contiguous with marsh. In addition, at this time the shallow bay was dominated by the polychaete Mediomastus spp. and oligochaetes, which are subsurface, deposit feeders (Gaston \& Nasci 1988, Whaley 1997) that may be unavailable to most predators. In contrast, S. alterni- flora marsh, ponds, and channels were dominated by chironomids, which are available and often consumed by estuarine predators (Sheridan 1979, Laughlin 1982, Rozas \& LaSalle 1990). Although infaunal densities in the shallow bay peaked in the fall and surpassed average densities in other habitat types, Mediomastus spp. continued to dominate the assemblage. The availability of prey in the shallow bay at this time, however, may have increased with the rise in densities of the polychaete Streblospio benedicti, which is a surface deposit feeder.

Factors that influence the abundance of infaunal prey populations in shallow estuarine areas are complex. The decline of infaunal densities in marsh and adjacent nonvegetated areas that we observed between spring and fall in our study may have resulted from grazing by predators (Cammen 1979, Kneib 1984). However, many environmental conditions (e.g., temperature, desiccation, sediment oxygen concentration) that vary with flooding patterns, elevation, and distance to edge also may control abundance of infaunal prey (Kneib 1984, Whaley 1997, Flynn et al. 1998). A combination of biotic or abiotic factors are likely responsible for the infaunal distributional patterns that we observed in our study. The identification of specific controlling factors will require further research that incorporates controlled experiments.

In summary, we observed distinct utilization patterns for different species of fishes and decapod crustaceans in a shallow region of Galveston Bay. None of the marsh or shallow nonvegetated habitat types we sampled was preferred by all species. However, the marsh surface and adjacent nonvegetated areas contained much higher densities of most animals than the shallow bay. Most fishery species that use the marsh surface were found in greatest abundance in low, shoreline marsh vegetation. In applying our results to habitat restoration in estuaries, we recommend creating a variety of marsh and contiguous shallow habitat types to enhance nekton biodiversity. To maximize fishery habitat, we recommend that within this mix of habitat types, greater emphasis be given to constructing low marsh edge by creating large areas of low marsh interspersed with a dense network of shallow channels and interconnected ponds.

Acknowledgements. This research was conducted through the Fishery Ecology Branch (FEB) of the Galveston Laboratory in the Southeast Fisheries Science Center (NOAA, National Marine Fisheries Service). The assistance of everyone in the FEB was essential for the successful completion of this project. In particular, we thank Timothy Baumer, F. Raymond Burditt, Marie Pattillo, Jeff Davis, Monica Daniels, Quenton Forrest, Todd Kihle, Gary McMahan, Mark Pattillo, and Michael Van for helping collect and process samples; Phillip Caldwell for producing Fig. 1; and Thomas J. Minello 
and Peter F. Sheridan for recommending changes that improved the manuscript. The suggestions offered by 3 anonymous reviewers also improved this paper. We thank Steve Owen for assistance with statistical analyses. This study was conducted at the request of the Beneficial Uses Group for the Houston-Galveston Ship Channel Project. We acknowledge the Port of Houston Authority and the National Marine Fisheries Service for funding this project.

\section{LITERATURE CITED}

Baltz DM, Rakocinski C. Fleeger JW (1993) Microhabitat use by marsh-edge fishes in a Louisiana estuary. Environ Biol Fish 36:109-126

Boesch DF, Turner RE (1984) Dependence of fishery species on salt marshes: the role of food and refuge. Estuaries 7 : $460-468$

Cain RL, Dean JM (1976) Annual occurrence, abundance and diversity of fish in a South Carolina intertidal creek. Mar Biol 36:369-379

Cammen LM (1979) The macro-infauna of a North Carolina salt marsh. Am Midl Nat 102:244-253

Castellanos DL (1997) Nekton use of submerged aquatic vegetation, marsh, and shallow unvegetated bottom in a Louisiana tidal freshwater ecosystem. MS thesis, University of Southwestern Louisiana, Lafayette

Cattrijsse A, Makwaia ES, Dankwa HR, Hamerlynck O. Hemminga MA (1994) Nekton communities of an intertidal creek of a European estuarine brackish marsh. Mar Ecol Prog Ser 109:195-208

Cicchetti G (1998) Habitat use, secondary production, and trophic export by salt marsh nekton in shallow water. PhD dissertation, The College of William and Mary in Virginia, Williamsburg

Flynn MN, Wakabara Y, Tararam AS (1998) Macrobenthic associations of the lower and upper marshes of a tidal flat colonized by Spartina alterniflora in Cananeia Lagoon estuarine region (Southeastern Brazil). Bull Mar Sci 63: $427-442$

Gaston GR, Nasci JC (1988) Trophic structure of macrobenthic communities in the Calcasieu Estuary, Louisiana. Estuaries 11:201-211

Gleason DF, Wellington GM (1988) Food resources of postlarval brown shrimp" (Penaeus aztecus) in a Texas salt marsh. Mar Biol 97:329-337

Hackney CT, Burbanck WD, Hackney OP (1976) Biological and physical dynamics of a Georgia tidal creek. Chesapeake Sci 17:271-280

Harper D (1992) Characterization of open bay benthic assemblages of the Galveston Estuary and adjacent estuaries from the Sabine River to San Antonio Bay. In: Green A (principal investigator) Status and trends of selected living resources in the Galveston Bay System, Gaiveston Bay National Estuary Program Publication GBNEP-19, Webster, p 413-450

Harrington RW Jr, Harrington ES (1961) Food selection among fishes invading a high subtropical salt marsh: from onset of flooding through the progress of a mosquito is sǘ. Ecuiugy $42.646-666$

Heck KL Jr, Coen LD (1995) Predation and the abundance of juvenile blue crabs: a comparison of selected east and gulf coast (USA) studies. Bull Mar Sci 57:877-883

Hettler WF Ji (1989) Nekton use of regularly-flooded saltmarsh cordgrass habitat in North Carolina, USA. Mar Ecol Prog Ser 56:111-118

Howe JC, Wallace RK, Rikard FS (1999) Habitat utilization by postlarval and juvenile penaeid shrimps in Mobile Bay, Alabama. Estuaries 22:971-979

Irlandi EA, Crawford MK (1997) Habitat linkages: the effect of intertidal saltmarshes and adjacent subtidal habitats on abundance, movement, and growth of an estuarine fish. Oecologia 110:222-230

Kneib RT (1984) Patterns of invertebrate distribution and abundance in the intertidal salt marsh: causes and questions. Estuaries 7:392-412

Kneib RT (1997) The role of tidal marshes in the ecology of estuarine nekton. Oceanogr Mar Biol Annu Rev 35: $163-220$

Kneib RT (2000) Salt marsh ecoscapes and production transfers by estuarine nekton in the southeastern U.S. In: Weinstein, MP (ed) Concepts and controversies in tidal marsh ecology. New Jersey Sea Grant, Fort Hancock (in press)

Kneib RT, Knowlton MK (1995) Stage-structured interactions between seasonal and permanent residents of an estuarine nekton community. Oecologica 103:425-434

Kneib RT, Wagner SL (1994) Nekton use of vegetated marsh habitats at different stages of tidal inundation. Mar Ecol Prog Ser 106:227-238

Laughlin RA (1982) Feeding habits of the blue crab, Callinectes sapidus Rathbun, in the Apalachicola estuary, Florida. Bull Mar Sci 32:807-822

Layman CA (1999) Fish assemblage structure in shallow water habitats on the Eastern Shore of Virginia barrier islands. MS thesis, University of Virginia, Charlottesville

Mclvor CC, Odum WE (1988) Food, predation risk, and microhabitat selection in a marsh fish assemblage. Ecology 69 : $1341-1351$

McTigue IA, Zimmerman RJ (1991) Carnivory versus herbivory in juvenile Penaeus setiferus (Linnaeus) and Penaeus aztecus (Ives). J Exp Mar Biol Ecol 151:1-16

Miltner RJ, Ross SW, Posey MH (1995) Influence of food and predation on the depth distribution of juvenile spot (Leiastomus xanthurus) in tidal nurseries. Can J Fish Aquat Sci 52:971-982

Minello TJ (1993) Chronographic tethering: a technique for measuring prey survival time and testing predation pressure in aquatic habitats. Mar Ecol Prog Ser 101:99-104

Minello TJ (1999) Nekton densities in shallow estuarine habitats of Texas and Louisiana and the identification of Essential Fish Habitat. In: Benaka L (ed) Fish habitat: essential fish habitat and habitat rehabilitation. Am Fish Soc Symp 22:43-75

Minello TJ, Webb JW Jr (1997) Use of natural and created Spartina alterniflora salt marshes by fishery species and other aquatic fauna in Galveston Bay, Texas, USA. Mar Ecol Prog Ser 151:155-179

Minello TJ, Zimmerman RJ (1983) Fish predation on juvenile brown shrimp, Penaeus aztecus Ives: the effect of simulated Spartina structure on predation rates. J Exp Mar Biol Ecol 72:211-231

Minello TJ, Zimmerman RJ (1992) Utilization of natural and transplanted Texas salt marshes by fishes and decapod crustaceans. Mar Ecol Prog Ser 90:273-285

Minello TJ, Zimmerman RJ, Martinez EX (1989) Mortality of young brown shrimp Penaeus aztecus in estuarine nurseries Trans Am Fish Sor 118:693-708

Minello TJ, Zimmerman R., Medina R (1994) The importance of edge for natant macrofauna in a created salt marsh. Wetlands 14:184-198

Orlando SP $\mathrm{J}_{\mathrm{I}_{j}}$ Rozas LP, Ward GH, Klein CJ (1991) Analysis of salinity structure and stability for Texas estuaries. Strategic Assessments Branch, NOS/NOAA. Rockville, Maryland 
Perez-Farfante I, Kensley B (1997) Penaeoid and sergestoid shrimps and prawns of the world; Keys and diagnoses for the families and genera. Mémoires du Muséum National d'Historie Naturelle Tome 175

Peterson GW, Turner RE (1994) The value of salt marsh edge vs interior as a habitat for fish and decapod crustaceans in a Louisiana tidal marsh. Estuaries 17:235-262

Pihl L, Rosenberg R (1982) Production, abundance, and biomass of mobile epibenthic marine fauna in shallow waters, western Sweden. J Exp Mar Biol Ecol 57:273-301

Rakocinski CF, Baltz DM, Fleeger JW (1991) Correspondence between environmental gradients and the community structure of marsh-edge fishes in a Louisiana estuary. Mar Ecol Prog Ser 80:135-148

Rice WR (1989) Analyzing tables of statistical tests. Evolution $43: 223-225$

Rogers BD, Herke WH, Knudsen EE (1992) Effects of three different water-control structures on the movements and standing stocks of coastal fishes and macrocrustaceans. Wetlands 12:106-120

Rountree RA, Able KW (1992) Fauna of polyhaline subtidal marsh creeks in southern New Jersey: composition, abundance and biomass. Estuaries 15:171-185

Rowe CL, Dunson WA (1995) Individual and interactive effects of salinity and initial fish density on a salt marsh assemblage. Mar Ecol Prog Ser 128:271-278

Rozas LP (1993) Nekton use of salt marshes of the Southeast region of the United States. In: Magoon OT, Wilson WS, Converse H, Tobin LT (eds) Coastal Zone '93, Vol 2. Proceedings of the 8th symposium on coastal and ocean management. American Society of Civil Engineers, New York, p 528-537

Rozas LP, Hackney CT (1984) Use of oligohaline marshes by fishes and macrofaunal crustaceans in North Carolina. Estuaries 7:213-224

Rozas LP, LaSalle MW (1990) A comparison of the diets of gulf killifish, Fundulus grandis Baird and Girard, entering and leaving a Mississippi brackish marsh. Estuaries 13: 332-336

Rozas LP, Minello TJ (1997) Estimating densities of small fishes and decapod crustaceans in shallow estuarine habitats: a review of sampling design with focus on gear selection. Estuaries 20:199-213

Rozas LP, Minello TJ (1998) Nekton use of salt marsh, seagrass, and nonvegetated habitats in a South Texas (USA) estuary. Bull Mar Sci 63:481-501

Rozas LP, Odum WE (1987) Fish and macrocrustacean use of submerged plant beds in tidal freshwater marsh creeks. Mar Ecol Prog Ser 38:101-108

Rozas LP, Reed DJ (1993) Nekton use of marsh-surface habitats in Louisiana (USA) deltaic salt marshes undergoing submergence. Mar Ecol Prog Ser 96:147-157

Rozas LP, Zimmerman RJ (1994) Developing design parameters for constructing ecologically functional marshes using dredged material in Galveston Bay, Texas. In: McNair EC $J_{r}$ (ed) Dredging ' 94 . Proceedings of the 2 nd international conference on dredging and dredged material placement. American Society of Civil Engineers, New York, p 810-822

Editorial responsibility: Gordon Thayer (Contributing Editor), Beaufort, North Carolina, USA
Rozas LP, Mclvor CC, Odum WE (1988) Intertidal rivulets and creekbanks: corridors between tidal creeks and marshes. Mar Ecol Prog Ser 47:303-307

Rozas LP, Zimmerman RJ, Burditt FR, Pattillo MC, Baumer TJ (1995) Development of design criteria and parameters for constructing ecologically functional marshes in Galveston Bay, Texas. Final Report to Port of Houston Authority, Houston

Ruiz GM, Hines AH, Posey MH (1993) Shallow water as a refuge habitat for fish and crustaceans in non-vegetated estuaries: an example from Chesapeake Bay. Mar Ecol Prog Ser 99:1-16

Sheridan PF (1979) Trophic resource utilization by three species of sciaenid fishes in a northwest Florida estuary, USA. Nor theast Gulf Sci 3:1-15

Thomas JL (1989) A comparative evaluation of Halodule wrightii Aschers, Spartina alterniflora Loisel and bare sand as nursery habitats for juvenile Callinectes sapidus (Rathbun). MS thesis, Texas A \& M University, College Station

Thomas JL, Minello TJ, Zimmerman RJ (1990) Abundance patterns of juvenile blue crabs (Callinectes sapidus) in nursery habitats of two Texas bays. Bull Mar Sci 46: $115-125$

Van Dolah RF (1978) Factors regulating the distribution and population dynamics of the amphipod (Gammarus palustris) in an intertidal salt marsh community. Ecol Monogr 48:191-217

Vince S, Valiela I, Backus N, Teal JM (1976) Predation by the salt marsh killifish Fundulus heteroclitus (L.) in relation to prey size and habitat structure: consequences for prey distribution and abundance. J Exp Mar Biol Ecol 23:255-266

Wenner EL, Beatty HR (1993) Utilization of shallow estuarine habitats in South Carolina, U.S.A., by postlarval and juvenile stages of Penaeus spp. (Decapoda: Penaeidae) J Crustacean Biol 13:280-295

Wermund EG, White WA, Paine JG, Waitt D (1992) Wetland plant communities, Galveston Bay system. The Galveston Bay National Estuary Program, Publication GBNEP-16, Webster

West DL, Williams AH (1986) Predation by Callinectes sapidus (Rathbun)within Spartina alterniflora (Loisel) marshes. J Exp Mar Biol Ecol 100:75-95

Whaley SD (1997) The effects of marsh edge and surface elevation on the distribution of salt marsh infauna and prey availability for nekton predators. MS thesis, Texas A \& M University, College Station

Zimmerman RJ, Minello TJ (1984) Densities of Penaeus aztecus, Penaeus setiferus, and other natant macrofauna in a Texas salt marsh. Estuaries 7:421-433

Zimmerman RJ, Minello TJ, Rozas LP (2000) Salt marsh linkages to productivity of penaeid shrimps and blue crabs in the Northern Gulf of Mexico. In: Weinstein MP (ed) Concepts and controversies in tidal marsh ecology. New Jersey Sea Grant, Fort Hancock (in press)

Zimmerman RJ, Minello TJ, Zamora G (1984) Selection of vegetated habitat by brown shrimp, Penaeus aztecus, in a Galveston Bay salt marsh. Fish Bull US 82:325-336

Submitted: February 24, 1999; Accepted: August 25, 1999

Proofs received from author(s): February 3, 2000 